\title{
Melatonin as a Chronobiotic and Cytoprotective Agent in Parkinson's Disease
}

\author{
Santiago Pérez-Lloret ${ }^{1,2 *}$ and Daniel P. Cardinali ${ }^{2}$ \\ ${ }^{1}$ Universidad Abierta Interamericana-Centro de Altos Estudios en Ciencias Humanas y de La Salud, Consejo Nacional de \\ Investigaciones Cientificas y Técnicas, UAI-CAECIHS. CONICET, Buenos Aires, Argentina, ${ }^{2}$ Faculty of Medical Sciences, \\ Pontificia Universidad Católica Argentina, Buenos Aires, Argentina
}

This article discusses the role that melatonin may have in the prevention and treatment of Parkinson's disease (PD). In parkinsonian patients circulating melatonin levels are consistently disrupted and the potential therapeutic value of melatonin on sleep disorders in PD was examined in a limited number of clinical studies using 2-5 mg/ day melatonin at bedtime. The low levels of melatonin MT1 and MT2 receptor density in substantia nigra and amygdala found in PD patients supported the hypothesis that the altered sleep/wake cycle seen in PD could be due to a disrupted melatonergic system. Motor symptomatology is seen in PD patients when about $75 \%$ of the dopaminergic cells

OPEN ACCESS

Edited by: Mkahmoud Iravani, University of Hertfordshire, United Kingdom

Reviewed by:

Marli Cardoso Martins-Pinge, State University of Londrina, Brazil

Enrico Sanna,

University of Cagliari, Italy

*Correspondence:

Santiago Pérez-Lloret

santiagop/@conicet.gov.ar

Specialty section:

This article was submitted to

Neuropharmacology,

a section of the journal

Frontiers in Pharmacology

Received: 07 January 2021 Accepted: 10 March 2021

Published: 15 April 2021

Citation:

Pérez-Lloret S and Cardinali DP (2021)

Melatonin as a Chronobiotic and

Cytoprotective Agent in

Parkinson's Disease.

Front. Pharmacol. 12:650597.

doi: 10.3389/fphar.2021.650597 in the substantia nigra pars compacta region degenerate. Nevertheless, symptoms like rapid eye movement (REM) sleep behavior disorder (RBD), hyposmia or depression may precede the onset of motor symptoms in PD for years and are index of worse prognosis. Indeed, RBD patients may evolve to an a-synucleinopathy within 10 years of RBD onset. Daily bedtime administration of 3-12 mg of melatonin has been demonstrated effective in RDB treatment and may halt neurodegeneration to PD. In studies on animal models of PD melatonin was effective to curtail symptomatology in doses that allometrically projected to humans were in the $40-100 \mathrm{mg} /$ day range, rarely employed clinically. Therefore, double-blind, placebo-controlled clinical studies are urgently needed in this respect.

Keywords: aging, glymphatic system, melatonin, neurodegeneration, oxidative stress, parkinson's disease, sleep

\section{INTRODUCTION}

With a prevalence of $1-4 \%$ in people $>60$ years of age, Parkinson's disease (PD) is the second most common neurodegenerative disorder (Tysnes and Storstein, 2017). Both genetic and environmental factors contribute to the evolution and progression of $\mathrm{PD}$ as a complex multifactorial disease. Indeed, several studies have pointed out to the involvement of genetic factors in the pathogenesis of PD, but much less is known about the contribution of environmental and lifestyle factors like e.g. circadian and sleep changes. Current PD diagnosis relies on the identification of motor clinical signs and symptoms, including bradykinesia, rigidity and rest tremor. In addition, patients with PD develop a wide range of non-motor manifestations including sleep and mood disturbances, cognitive impairment and dementia, and autonomic nervous system dysfunction many times in advance to motor dysfunction (Poewe et al., 2008). Since a loss of 50-80\% of dopaminergic neurons in the substantia nigra pars compacta is needed for the first motor signs occur (Cheng et al., 2010), 
neuroprotection strategies at this stage tends to be unsuccessful. because brain injury has been ongoing for years.

A multifactorial etiology of $\mathrm{PD}$ as a neurodegenerative disorder is advocated. The loss of dopaminergic neurons has been attributed to a low-degree inflammation and oxidative damage (Abramov et al., 2020; Singh and Devasahayam, 2020). As main mediators of inflammatory responses, the microglia becomes activated and release reactive oxygen species and proinflammatory cytokines in PD (Kam et al., 2020). In addition, a dysfunctional blood brain barrier is involved in the progression of the disease and a faulty metabolism and elimination of putative $\mathrm{PD}$ toxins by the glymphatic system occur (Sundaram et al., 2019). This is associated with infiltration of peripheral immune cells resulting in enhanced inflammation. Excessive accumulation of iron in the substantia nigra is another factor reported to have a pathogenic role in PD as it promotes enhanced generation of reactive oxygen species (Mochizuki et al., 2020). Hence, the effectiveness of administering antioxidants for neurodegeneration prevention has been proposed but albeit questioned (Davies et al., 2017).

Melatonin is present in all aerobic phyla and may have therapeutic significance both as a cytoprotective and chronobiotic properties (Cardinali, 2019b). The pineal gland accounts for more than $95 \%$ of circulating melatonin levels and the decrease of these levels is typical of advancing age in humans (Claustrat and Leston, 2015). In this article we will review the clinical use of melatonin in $\mathrm{PD}$, with the discussion of animal studies being restricted to their relevance for the melatonin doses used in humans. Melatonin's cytoprotective effect and clinical usefulness in neurodegenerative disorders are discussed elsewhere (Cardinali, 2019b).

\section{ALTERATIONS IN BIOLOGICAL RHYTHMS IN PARKINSON'S DISEASE AND ITS RELEVANCE FOR THE NEURODEGENERATIVE PROCESS}

There is abundant evidence pointing out to the existence of disturbances in biological rhythms in PD. In one study, bilateral nigrostriatal lesions with 6-hydroxydopamine (6OHDA) in rats disrupted heart rate, temperature and activity rhythms (Ben and Bruguerolle, 2000). Lesioned animals showed significantly decreased mean daily values and a phase advance of circadian rhythms. Decreased amplitude was also observed in heart rate rhythms. Abolition of heart rhythms was also observed in another study in 6-OHDA-lesioned rats (Henderson et al., 2010). However, alterations in biological rhythms were not observed after 1-methyl-4-phenyl-1,2,3,6-tetrahydropyridine (MPTP) lesions in C57bl/6 mice maintained in light: dark (L: D) 12:12 (Leng et al., 2004)) or in non-human primates (Barcia et al., 2004) (REF). Notwithstanding, in the latter, locomotor activity and hormonal rhythms alterations in become evident when animals were challenged by exposure to constant light (Fifel et al., 2014). Administration to rats placed in L:D 12:12 of rotenone, a pesticide with toxic effects in dopaminergic neurons, produced a reduction in the mean value and amplitude of the circadian locomotor activity and body temperature rhythms (Lax et al., 2012). Lower interdaily phase stability, and higher rhythm fragmentation were also observed in rats.

The exploration of biological rhythms in transgenic models of parkinsonism have yielded interesting results. A study in a transgenic mouse PD model overexpressing alpha-synuclein, found deposition of this protein in the suprachiasmatic nuclei (SCN), which bears the master biological clock (Kudo et al., 2011). Results in these animals suggested a weakened circadian system time, which may thus be a core feature of PD.

Results in experimental parkinsonism also show altered expression of the clock genes, Indeed, reductions in PER2, which is one of the genes that control rhythms at a cellular level, levels were observed in the dorsal striatum of 6-OHDA lesioned rats (Hood et al., 2010). Circadian expression of clock genes in the SCN were also abolished after rotenone administration to rats (Lax et al., 2012).

Antiparkinsonian medications used to treat PD may impact on the biological rhythms on their own. In 6OHDA-lesioned, treatment with L-dihydroxyphenylalanine (L-DOPA) produced an increase in mean daily values of temperature and heart rate (Simon et al., 2000). While the temperature rhythm's amplitude was increased, heart rate rhythm's amplitude was reduced. Interestingly, these effects were in opposition to those imposed by 6-OHDA lesions (Ben and Bruguerolle, 2000). Thus, L-DOPA corrected to some extent the alterations of temperature and heart rate rhythms. Further benefits may be offered by circadian infusions of L-DOPA, if they are capable to mimic the normal dopamine rhythm (Boulamery et al., 2010). Alterations in biological rhythms have been also observed in the transgenic mouse MitoPark model of PD (Kudo et al., 2011).

The hypothesis that biological rhythms could, in turn, affect the development of experimental parkinsonism was tested in a study in which enucleation of the lateral hypothalamus was performed in the 6-OHDA-lesioned rats kept in L:D 12:12 (Fifel and Cooper, 2014). Removal of the lateral hypothalamus disrupts the retino-hypothalamic tract and leads to altered biological rhythms. Compared to 6-OHDA lesions alone, removal of the lateral hypothalamus ipsilateral to the side of the 6-OHDA lesion, was associated with impairments of horizontal movement, limb retraction, ambulation and spontaneous or L-DOPA induced turning (Willis et al., 2008).

Disturbances of biological rhythms have also been found in PD patients. For example, lower expression of BMAL1 has been observed in patients (Cai et al., 2010; Ding et al., 2011; Breen et al., 2014). Furthermore, polymorphism in ARNTL and PER1 genes were observed more frequently in a sample of 1253 Chinese PD cases as compared to 1342 healthy controls, thus reinforcing the idea that circadian alterations might contribute to the neurodegenerative process in PD. One study reported alterations in the body temperature rhythm, which were correlated to the self-reported severity of Rapid Eye Movement (REM) Sleep Behavior Disorder (RBD) symptoms (Zhong et al., 2013). Alterations in cortisol circadian rhythm have also been 
documented in PD, with elevated levels of this hormone during nighttime and early morning (Hartmann et al., 1997). Disturbances in the blood pressure rhythm, with nighttime hypertension, have also been observed (Ahsan Ejaz et al., 2006; Berganzo et al., 2013).

\section{SLEEP DISORDERS IN PARKINSON'S DISEASE}

Sleep disorders affect PD patients frequently and impact negatively on quality of life (Gallagher et al., 2010; Avidan et al., 2013). Insufficient sleep interferes with routine activities and can also aggravate motor symptoms in PD. Some of the most frequent disorders are RBD, insomnia, restless legs syndrome (RLS) and periodic limb movement disorder, circadian rhythm sleep disorders (CRSD), nocturia, sleep disordered breathing (SBD) and excessive daytime sleepiness (EDS). In the following paragraphs we will review the essential aspects of each condition.

$\mathrm{RBD}$ is a REM parasomnia characterized by movements occurring during REM sleep, in the context of dreaming (i.e. patients "play along" their dreams). Somatic muscle atonia occurs normally during REM sleep, which is lost in RBD. RBD prevalence in PD ranges between 39 and 46\% (SixelDöring et al., 2011; Neikrug et al., 2013). In some instances, $\mathrm{RBD}$ may precede the diagnosis of $\mathrm{PD}$, but $\mathrm{PD}$ patients may also develop this condition after receiving the clinical diagnosis. For establishing the diagnosis of RBD, a history or visualization of dream enactment along with polysomnographic evidence of REM sleep without atonia is required (American Academy of Sleep Medicine, 2015). Dream enactment can be assessed by means of screening questionnaires, but they demonstrate low specificity.

Insomnia can be defined as inadequate sleep quality reported subjectively. It constitutes considered a symptom resulting from different pathological processes. In $\mathrm{PD}$, the most commonly reported complaint is sleep fragmentation (Gómez-Esteban et al., 2006). Poor sleep in PD has been reported in between 20 and 80\% of patients (Gjerstad et al., 2007; Porter et al., 2008). The assessment of insomnia is achieved using questionnaires. Parkinson's disease Sleep Scale (PDSS), Scales for Outcomes in Parkinson's disease Sleep (SCOPA-Sleep), and the Pittsburgh Sleep Quality Index (PSQI) may be used for the subjective assessment of sleep in PD (Högl et al., 2010). The PDSS and SCOPA-Sleep scales were conceived specifically for the assessment of PD patients (Chaudhuri et al., 2002; Marinus et al., 2003). The SCOPA-Sleep is shorter and thus easier to use. The PSQI is commonly used to assess sleep quality in PD or other groups of patients (Buysse et al., 1989). Polysomnography may be indicated with another primary sleep disorder, such as sleep apnea, is suspected.

RLS is a sleep-related movement disorder that may affect patients with PD, with a prevalence of 3-21.3\% (Loo and Tan, 2008; Azmin et al., 2013; Rana et al., 2013). Some studies suggest RLS may be a risk factor to develop PD. However, the opposite has been observed (i.e., PD being a risk factor for RLS) (Calzetti et al., 2014; Wong et al., 2014) The diagnosis of RLS requires the presence of an urge to move the legs, which may be accompanied by an uncomfortable sensation (American Academy of Sleep Medicine, 2015). This sensation occurs with rest/inactivity, most commonly at night or in the evening, and is at least partially relieved by movement. According to the ICSD III criteria, significant distress or result in sleep impairment should also result from symptoms. An immobilization test has been developed as an objective marker of RLS (De Cock et al., 2012). Patients are instructed to lay still for $1 \mathrm{~h}$ at night. They are requested to report the severity of leg discomfort on a scale of 0 (no discomfort) to 100 (extreme discomfort) every $10 \mathrm{~min}$. Notwithstanding, its utility for detecting alternative diagnoses of RLS in PD has not been evaluated.

PLMD refers to the presence of periodic limb movements during sleep (PLMS), which lead to significant impairment of sleep and/or functioning (American Academy of Sleep Medicine, 2015). The diagnosis of PLMD requires > 15 PLMS per hour. While PLMS are frequently seen in patients with RLS; they can also be seen in isolation in the elderly population (Ancoli-Israel et al., 1991).

CRSD is characterized by disturbances of the 24-hs sleep-wake rhythm. As mentioned earlier, there is a considerable alteration of the biological clock in PD. The impact of CRSD in PD has only been recently appreciated, and further research is warranted.

Nocturia is reported in $60-80 \%$ of PD patients (Winge et al., 2006). Risk factors for nocturia include male sex, older age, older age of PD onset, and increased PD duration and severity (Rana et al., 2014). The pathogenesis of this condition is multifactorial. Detrusor muscle hyperactivity and polyuria may be related to nocturia (Xue et al., 2014). Dopaminergic medications, sleep apnea, and other factors or conductions may aggravate the syndrome (Picillo et al., 2014). Assessment of nocturia in PD patients can be performed by questionnaires, such as The Movement Disorders Society-Unified Parkinson's disease Rating Scale (MDS-UPDRS), the Parkinson's disease sleep scale version-2 and SCOPA-sleep (Marinus et al., 2003; Trenkwalder et al., 2011).

SDB affects $15-76 \%$ of PD patients (Chahine et al., 2017). Obstructive and restrictive pulmonary pathology as well as an abnormal response to hypercapnia, are the most frequently described patterns of SDB in PD (Sabaté et al., 1996; Monteiro et al., 2012). PD patients may be prone to develop SDB after developing pulmonary dysfunction. Polysomnography is required for the diagnosis of $\mathrm{SDB}$.

Finally, EDS may affect $20-60 \%$ of PD patients (Chahine et al., 2017). EDS may precede PD diagnosis or may be observed during the course of treatment with dopaminergic agents (Buskova et al., 2011) EDS has a considerable impact in daily activities, quality of life, and caregiver burden (Ozdilek and Gunal, 2012). The Epworth sleepiness scale (ESS) is the measure of choice for the assessment of EDS in PD (Hagell and Broman, 2007). Objective assessment of EDS may be performed by means of the multiple sleep latency test (MSLT) and maintenance of wakefulness test (MWT). These tests evaluates the ability of the subject to maintain wakefulness or to fall asleep, respectively (American Academy of Sleep Medicine, 2015). 


\section{BASIC BIOLOGY OF MELATONIN RELEVANT TO PARKINSON'S DISEASE}

"Chronobiotics" are drugs that synchronize or increase the amplitude of circadian rhythms, melatonin being its natural prototype (Dawson and Armstrong, 1996; Cardinali et al., 2008). The essential role of melatonin as a chronobiotic is defined by its prominent light/dark rhythm in circulation. Melatonin inhibits the wakefulness-facilitating activity of the SCN in the late afternoon, triggering sleep (Lavie, 1997; Lewy et al., 2006). As the secretion of pineal melatonin is proportional to the length of the night, it provides the neuroendocrine apparatus with fundamental information on the time of year regulate ng seasonality (Pandi-Perumal et al., 2008).

Although more than $90 \%$ of circulating melatonin derives from the pineal gland (Claustrat and Leston, 2015) there is ample evidence that it is synthesized locally in most cells, tissues, and organs (Acuña-Castroviejo et al., 2014). Indeed, the idea is held that that melatonin is produced in all animal cells that have mitochondria (Tan and Reiter, 2019) and that a mitochondrial protective function is critical for cytoprotection (Hardeland et al., 2011).

Melatonergic receptors (MT1 and MT2) are responsible for the chronobiotic function of melatonin. Both receptors are members of the superfamily of membrane receptors associated with G proteins (G-protein-coupled receptors, GPCR) (Dubocovich et al., 2010). A third member of the melatonin receptor family, GPR50, displays high sequence homology with MT1 and MT2 but rather than binding melatonin or any other known ligand, it forms homo and heteromers with MT1 and MT2 as well as with other GPCRs (Cecon et al., 2018).

MT1 and MT2 receptors have been identified in SCN and in several CNS areas, including the cerebral and cerebellar cortex and the midbrain (Ng et al., 2017). In the midbrain, MT1 and MT2 receptors are related to modulation of the nigrostriatal and mesocorticolimbic dopaminergic pathways, possibly related to the pathophysiology of PD. Functional melatonin receptors have been localized in substantia nigra, nucleus accumbens, ventral tegmental areas and caudate-putamen ( $\mathrm{Uz}$ et al., 2005). The substantia nigra of PD patients exhibited a decreased expression of MT1 and MT2 receptors (Adi et al., 2010a).

Due to its amphiphilic properties melatonin crosses readily cell membranes. Calmodulin and tubulin are among the cytoplasmic proteins that interacts with melatonin (JiménezRubio et al., 2012). Melatonin also enters the cell nucleus and interacts indirectly with orphan RZR/ROR superfamily of receptors (Hardeland et al., 2011) through the activation of sirtuin-1, which affects the circadian accessory oscillator RORa 1 (Hardeland, 2018b).

The cytoprotective activity of melatonin cannot be explained by interaction with MT1 and MT2 receptors only. As mentioned, the amounts of intracellular melatonin greatly exceeds those found in circulation (Acuña-Castroviejo et al., 2014). Intramitochondrially synthesized melatonin is retained within the organelle and the melatonin doses capable to modify the intracellular melatonin concentration are much higher than those used clinically as a chronobiotic (Venegas et al., 2013).
Although in cell cultures, some physiologically relevant effects of melatonin are revealed at doses in the range of $10^{-8}-10^{-9} \mathrm{M}$ (Zemková and Vaněček, 1997) for most studies on cytoprotective effects in animals pharmacological doses that clearly exceed receptor saturation were employed (Cardinali, 2019a).

This review focuses on the effects of melatonin on neurodegeneration in animal models of $\mathrm{PD}$ in relation to the possible human doses to be employed. For recent reviews related to the activity of melatonin to reverse altered signaling mechanisms in neurodegeneration, including impaired autophagic integrity, proteostasis dysfunction and abnormalities in Notch, $\mathrm{Wnt} / \mathrm{B}$ and insulin signaling pathways see (Shukla et al., 2019; Tamtaji et al., 2020; Tan et al., 2020).

The melatonin antioxidant and scavenging effects on free radicals occurring in both the cytoplasm and the cell nucleus, are largely independent of receptors. Besides being a free radical scavenger itself, there is an oxidation-drive conversion of melatonin to compounds with higher antioxidant activit. In addition, melatonin displays a strong indirect antioxidant effect by stimulating the synthesis of antioxidant enzymes and by inhibiting that of pro-oxidant enzymes. In protecting against oxidative damage melatonin is more effective that vitamin $\mathrm{C}$ and E (Reiter et al., 2017). Moreover, melatonin facilitates the effects of other antioxidants, like Trolox or vitamin C. A stabilizing activity of melatonin on mitochondrial membrane explain several cytoprotective and antiapoptotic effects exerted by melatonin under ischemic conditions (not related to free radicals) (Tan and Reiter, 2019).

Immunomodulation by melatonin includes pro-inflammatory and anti-inflammatory effects (Carrillo-Vico et al., 2013; Hardeland, 2018a). Anti-inflammatory actions of melatonin have been demonstrated in low-grade inflammation, like neurodegenerative processes or aging as well as in high-grade inflammation such as sepsis, ischemia/reperfusion or brain injury.

Melatonin anti-inflammatory properties are related to the inhibition of nuclear factor $\kappa \mathrm{B}(\mathrm{NF} \kappa \mathrm{B})$ binding to DNA, and of cyclooxygenase (Cox) (Cardinali et al., 1980) (mainly Cox-2) (Deng et al., 2006)), as well as to down-regulation of inducible nitric oxide synthase receptors (Hardeland et al., 2011). Other signaling pathways include up-regulation of nuclear factor erythroid 2-related factor 2 and of toll-like receptor-4 activation and high-mobility group box-1 signaling receptors, and prevention of NLRP3 inflammasome activation by melatonin (Hardeland et al., 2011). Collectively, these effects of melatonin result in increased production of anti-inflammatory cytokines and reduced levels of pro-inflammatory cytokines (Carrillo-Vico et al., 2013; Hardeland, 2018a).

In $\mathrm{PD}$ patients, $\gamma$-aminobutyric acid (GABA)-ergic dysregulation in basal ganglia has been documented by means of magnetic resonance spectroscopy (Huang et al., 2019). Since striatal dopaminergic axons release GABA, dopaminergic neurodegeneration may lead to a GABA hypofunction in basal ganglia circuits (O'Gorman Tuura et al., 2018). The trigger of neurodegenerative processes could be followed by a loss of the inhibitory tone of GABA and accumulation of abnormal levels of intracellular calcium. In support of this view, the GABA agonist 
baclofen has been shown to alleviate motor symptoms and protect dopamine cell bodies in a PD murine model (Lozovaya et al., 2018).

The GABAergic system is involved in melatonin-mediated neuroprotection. In fact, melatonin exerts anti-excitatory and sedative effects (Golombek et al., 1996; Caumo et al., 2009) and there is information that melatonin protects neurons from $B$ amyloid peptide toxicity through the activation of GABAergic receptors (Louzada et al., 2004). An allosteric modulation of $\mathrm{GABA}_{\mathrm{A}}$ receptors by melatonin was indicated by the efficacy of the benzodiazepine antagonist flumazenil, and the lack of activity of the melatonin receptor antagonist luzindole, to modify upregulation of GABA activity by melatonin (Cheng et al., 2012).

The anti-excitotoxic activity of melatonin should be also considered. For example, melatonin administration protects CA1 neurons in the hippocampus from transient ischemia (Cho et al., 1997) or from death due to high doses of glucocorticoids (Furio et al., 2014). Kainate, an agonist of the ionotropic glutamate receptor, induces neuronal death, an effect also prevented by melatonin (Giusti et al., 1996). As revealed by the lack of effects of specific blockers, melatonin receptors do not participate in the anti-excitotoxic activity of melatonin (Escames et al., 2004).

Finally, the recognized activity of melatonin in reversing the effects of an increased insulin resistance (IR) (Amaral et al., 2019) is also of importance in relation to PD. Systemic and brain IR are found in PD (Aviles-Olmos et al., 2013; Athauda and Foltynie, 2016) and type-2 diabetes (T2D) is a risk factor for the subsequent development of PD (De Pablo-Fernandez et al., 2018). The possible association between $\mathrm{PD}$ and $\mathrm{T} 2 \mathrm{D}$ lies in their proteinopathic characteristics. Lewy bodies and neurites, composed of amyloid aggregates of misfolded $\alpha$-synuclein, are the pathological signs of PD (Horvath and Wittung-Stafshede, 2016). T2D also shows pancreatic amyloid deposits, due to the aggregation of islet amyloid polypeptide (amylin). Deposit of amylin accelerates the formation of $\alpha$-synuclein amyloid (Horvath and Wittung-Stafshede, 2016). Moreover, studies in pancreatic B-cells of patients with a neuropathological diagnosis of synucleinopathy also supported a direct interaction between amylin and $\alpha$-synuclein (Martinez-Valbuena et al., 2018).

\section{STUDIES ON THE ACTIVITY OF MELATONIN IN ANIMAL MODELS OF PARKINSON'S DISEASE}

Besides the degeneration of DA-containing neurons in the substantia nigra pars compacta $(\mathrm{SNpc}), \mathrm{PD}$ is considered a progressive disease that affects various neurotransmitter systems. A major argument in this respect is the demonstration that Lewy bodies are located not only in DA neurons but also in raphe nuclei serotonergic neurons, in brainstem noradrenergic neurons and in specific cholinergic neurons all over the CNS (Nutt and Bohnen, 2018). Nonmotor symptoms in $\mathrm{PD}$, like gastrointestinal, genitourinary and cardiorespiratory disorders, neuropsychiatric, visual, and sleep-related disorders and anosmia can thus be explained. In fact, since the preclinical non-motor phase of PD can span more than 20 years, the importance of neuroprotection in this regard is evident.

Microglial activation, astrogliosis, and lymphocytic infiltration are the inflammatory patent of PD (Michel et al., 2016). The aggregation of fibrillar $a$-synuclein is typical of PD and other Lewy body diseases (Marmion and Kordower, 2018). Mitochondrial dysfunction plays a role in this process, as free radicals promote protein folding and aggregation.

Popular animal models of altered brain DA function are the injection of 6-OHDA, or of the neurotoxin MPTP in the nigrostriatal pathway of the rat (Barker and Björklund, 2020). MPTP toxicity is selective for SNpc neurons in non-human primates. Due to its potential to cause disease in humans and in subhuman primates, MPTP is generally preferred to mimic parkinsonism in animals. However, a major drawback of this model is the absence of other neuronal losses in addition to the damaged nigrostriatal dopaminergic system (Marmion and Kordower, 2018).

The effect of melatonin in animal models of PD is summarized in Table 1. From the melatonin doses used in each case, the human equivalent dose of melatonin for a $75^{\circ} \mathrm{kg}$ adult was calculated by allometry. Allometry is applied to propertie.s whose proportions change as a function of size, in contrast to isometry, whose relation to size is constant (Huang and Riviere, 2014). Body surface area, rather than body weight, is correlated in various mammalian species with numerous biological parameters, including basal metabolism, caloric expenditure, oxygen utilization, blood volume, kidney function and circulating plasma proteins (Reagan-Shaw et al., 2008). Allometry is commonly used to determine doses in phase I human drug clinical trials or to predict drug pharmacokinetic parameters in children, thus decreasing the incidence of toxicity accidents. As summarized in Table 1, theoretical human equivalent doses of melatonin calculated from the results in animals are two-three orders higher than those commonly used in humans.

In most studies of Table $\mathbf{1}$ melatonin was administered previously to the toxin and are thus indicating the neuroprotective activity of melatonin to prevent the death of dopaminergic neurons. However, in some studies this neuroprotective effect of melatonin is observed in animal models of PD regardless of the motor benefits. For example, post-treatment with melatonin for 28 days preserved DA levels and tyrosine hydroxylase-positive neurons in rotenone-injured rats and improved depressive behavior in the absence of significant improvement in motor deficit (Bassani et al., 2014). Furthermore, when evaluating the effects of a slow-release melatonin preparation by intracerebroventricular implants in rats injected with 6-OHDA or MPTP, melatonin actually impaired motor performance (Willis and Armstrong, 1999). These effects could be explained by the inhibition of DA release given by high concentrations of the methoxyindole (Zisapel et al., 1982). Regardless of the discrepancies cited, the preventive activity of melatonin in neurodegeneration related to PD is generally accepted (Lin et al., 2007; Chang et al., 2012; Leeboonngam et al., 2018). 
TABLE 1 | Effects of melatonin in animal models of PD.

\begin{abstract}
References
\end{abstract}
Parkinsonism

experimental model

\section{Melatonin (dose} and administration route

Effects of melatonin

Melatonin

equivalent

dose

for a $75 \mathrm{~kg}$

adult patient $^{\mathrm{a}}$

Burton et al. (1991)
Acuña-Castroviejo
et al. (1996)
Jin et al. (1998)
Joo et al. (1998)
Kim et al. (1998)
DABBENI-SALA et al.
(2001)
Aguiar et al. (2002)

6-OHDA SNc injections (Wistar rats)

$\mathrm{MPP}^{+}$injection (C57BL/6 mice)

$\mathrm{MPP}^{+} \mathrm{SNc}$ injection (Sprague-Dawley rats)

6-OHDA striatal injections (Sprague-

Dawley rats)

6-OHDA striatal injections (SpragueDawley rats)

6-OHDA nigral injections (Sprague-

Dawley rats)

6-OHDA SNc injections (Wistar rats)

\section{Chen et al. (2002)}

Khaldy et al. (2003)

Sharma et al. (2006)

Singh et al. (2006)

Saravanan et al. (2007)

Huang et al. (2009)

Tapias et al. (2009)

Patki and Lau, (2011)

Singhal et al. (2011)

Gutierrez-Valdez et al.

(2012)

Brito-Armas et al.

(2013)

Zaitone et al. (2013)

Bassani et al. (2014)

Yildirim et al. (2014)

Naskar et al. (2015)

Ozsoy et al. (2015)

Carriere et al. (2016)

Li et al. (2017)

López et al. (2017) mice

$\mathrm{MPP}^{+} \mathrm{SNc}$ injections (Wistar rats)

$\mathrm{MPP}^{+}$injection (C57BL/6 mice)

6-OHDA striatal injections (SpragueDawley rats)

6-OHDA striatal injections (SpragueDawley rats)

Dawley rats)

$\mathrm{MPP}^{+} \mathrm{SNc}$ injections (Wistar rats)

MPTP injection (C57BL/6 mice)

6-OHDA media forebrain bundle injections (Wistar rats)

Lentiviral vectors encoding mutant human a-synuclein injections in the SNc (Sprague-Dawley)

MPTP injections (swiss mice)

Wistar rats were i.p. injected with rotenone

6-OHDA injections into the medial forebrain bundle (Wistar rats)

MPTP treatment in BALB/c mice

6-OHDA injections into the medial forebrain bundle (Wistar rats)

Rotenone injections (Sprague Dawley rats)

6-OHDA nigral injections (Wistar rats)

C57BL/6 mice receiving MPTP
Rotenone nigral injection (Sprague-

Maneb plus paraquat (swiss mice)
1 and $10 \mathrm{mg} / \mathrm{kg}$, i.p

$10 \mathrm{mg} / \mathrm{kg}$, i.p

$10 \mathrm{mg} / \mathrm{kg}$, i.p

3 and $10 \mathrm{mg} / \mathrm{kg}$, i.p

3 or $10 \mathrm{mg} / \mathrm{kg}$, i.p

$50 \pm 7.5 \mu \mathrm{g} / \mathrm{h}, \mathrm{s} . \mathrm{C}$

2, 5, 10, and $25 \mathrm{mg} / \mathrm{kg}$, i.p

$10 \mathrm{mg} / \mathrm{kg}$, i.p.)

5 or $10 \mathrm{mg} / \mathrm{kg}$ i.p

$4 \mu \mathrm{g} / \mathrm{ml}$, p.o

$0.5 \mathrm{mg} / \mathrm{kg}$, i.p

10,20 , or $30 \mathrm{mg} / \mathrm{kg}$, i.p

$10 \mathrm{mg} / \mathrm{kg}$, i.p

$20 \mathrm{mg} / \mathrm{kg}$, s.c

$5 \mathrm{mg} / \mathrm{kg}$, i.p

$30 \mathrm{mg} / \mathrm{kg} /$ day, i.p

$10 \mathrm{mg} / \mathrm{kg}$, p.o

$10 \mathrm{mg} / \mathrm{kg} /$ day, i.p

5 or 10 mg/ kg/day, p.o

$10 \mathrm{mg} / \mathrm{kg}$, i.p

$10 \mathrm{mg} / \mathrm{kg}$, i.p

10, 20 or 30 mg/ kg, i.p

$10 \mathrm{mg} / \mathrm{kg} /$ day, i.p

$4.0 \mu \mathrm{g} / \mathrm{ml}$, p.o

$5 \mathrm{mg} / \mathrm{kg}$, i.p

$10 \mathrm{mg} / \mathrm{kg}$ s.c
Reduced apomorphine-induced rotational behavior

Reduced lipid peroxidation and TH-positive neuronal loss in striatum after $\mathrm{MPP}^{+}$ Reduced lipid peroxidation and protected against DA neuronal loss induced by MPP ${ }^{+}$ Increased striatal DA synthesis and levels

Reduced motor deficit and improved dopaminergic neurons survival

Prevented apomorphine-induced rotational behavior and mitochondrial damage

Prevented apomorphine-induced rotational behavior and depletion of striatal DA and serotonin levels

Decreased $\mathrm{MPP}^{+}$-induced toxicity and

recovered GSH levels

Increase in mitochondrial complex I activity in nigrostriatal neurons

Normalized motor deficits and augmented TH immunoreactivity

Prevented apomorphine-induced rotational behavior

Reduced levels of hydroxyl radicals in mitochondria and increased GSH levels and antioxidant enzymes activities in SNc

Reduced DA neurons apoptosis

Reduced mitochondrial NO levels, reduced lipid peroxidation and improved complex I activity in striatum and $\mathrm{SNc}$

Reduced DA neurons loss and locomotor activity deficits. Improved mitochondrial respiration, ATP production, and antioxidant enzyme levels in SNc

Reduced lipid peroxidation, TH-positive neurons death, and apoptosis

Improved motor performance without causing dyskinesia. Improved DA neurons survival Improved DA neurons survival

12 and $120 \mathrm{mg}$

$60 \mathrm{mg}$

$120 \mathrm{mg}$

36 and $120 \mathrm{mg}$

36 and $120 \mathrm{mg}$

$15 \mathrm{mg}$

24-300 mg

$120 \mathrm{mg}$

30 and $60 \mathrm{mg}$

$6 \mathrm{mg}$

$6 \mathrm{mg}$

120, 240 and

$360 \mathrm{mg}$

$120 \mathrm{mg}$

$120 \mathrm{mg}$

$30 \mathrm{mg}$

$180 \mathrm{mg}$

$120 \mathrm{mg}$

$120 \mathrm{mg}$

Improved motor performance, striatal DA level, GSH, and antioxidant enzyme activities, and reduced lipid peroxidation. Improved motor response to L-DOPA

Improved DA neurons survival and increased DA levels

Reduced oxidative damage and apoptosis of DA neurons

Improved DA neurons survival and enhanced the therapeutic effect of L-DOPA

Improved DA neurons against antioxidant enzyme activities and reduced lipid peroxidation

Reduced motor deficit and DA neurons loss

Reduced DA neuronal damage

Preserved mitochondrial oxygen consumption, increased NOS activity and reduced locomotor activity

(Continued on following page) 
TABLE 1 | (Continued) Effects of melatonin in animal models of PD.

References

\section{Parkinsonism}

experimental model
Melatonin (dose and administration route
Effects of melatonin

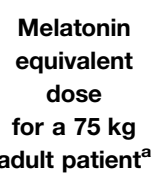

Reduced DA loss and improved mitochondrial complex-I activity in SN Improved motor function by upregulation of tyrosine hydroxylase in striatum. Reduced DA neuron damage
120, 240 and $360 \mathrm{mg}$ $240 \mathrm{mg}$

Rasheed et al. (2018) Rotenone injections (Wistar rats) 20 mg/ kg, i.p

a as calculated by normalization of body surface area (Reagan-Shaw et al., 2008) DA = dopamine; 6-OHDA = 6-hydroxydopamine; MPTP = 1-methyl-4-phenyl-1,2,3,6-tetrahydropyridine; MPP+ = 1-methyl-4-phenylpyridinium; i.p. = intraperitoneal; s.c. = subcutaneous; p.o. = oral administration (in drinking water).

The accumulation and spread of oligomeric forms of neurotoxic a-synuclein could be explained by an insufficient autophagic-lysosomal clearance (Boland et al., 2018). In addition, other pathways of clearance are disrupted, such as the ubiquitin-proteasome system, chaperone-mediated autophagy, extracellular protease clearance, or the glymphatic system (Boland et al., 2018). The expression of the water channel aquaporin 4 (AQ4) in the glymphatic system is severely altered in PD brains (Hoshi et al., 2017) and this may explain why the levels of $a$-synuclein in the CSF are inversely correlated with symptoms in PD patients (Schirinzi et al., 2019). The association of sleep loss with impaired glymphatic clearance is important in PD because RBD is a prodrome of PD. In mice, injection of melatonin to animals increased glymphatic clearance (Pappolla et al., 2018). In PD patients melatonin preserves sleep (Daneshvar Kakhaki et al., 2020).

DA supplementation by the administration of its precursor L-DOPA is an effective treatment to reduce motor symptoms in PD patients. However, long-term administration of -L-DOPA causes undesired motor sequels like dyskinesias (Remington, 2007). Furthermore, the production of neurotoxins like 6-OHDA is detected after administration of a high dose of L-DOPA. Melatonin, but not L-DOPA, restored the neuronal density in the striatal column of MPTP-treated mice strongly supporting the use of melatonin as an adjunct to L-DOPA therapy in PD patients (Naskar et al., 2015). In the MPTP monkey model of PD, the combined treatment of melatonin and L-DOPA significantly reduced nighttime sleep fragmentation and daytime sleep episodes, indicating that melatonin treatment can be useful in treating sleep disorder in patients with PD (Belaid et al., 2015).

\section{CLINICAL USE OF MELATONIN IN PARKINSON'S DISEASE AND RBD}

A phase advance in nocturnal melatonin secretion was observed in PD patients treated with L-DOPA (Fertl et al., 1993; Bordet et al., 2003). Patients treated with L-DOPA showed increased melatonin secretion during the day, perhaps as an adaptive response to neurodegeneration (Bordet et al., 2003). PD patients, particularly those showing excessive daytime sleepiness, exhibited a reduced amplitude of the circulating melatonin rhythm (Videnovic et al., 2014). A chronobiologic therapy for non-motor manifestations of $\mathrm{PD}$, comprising the scheduled exposure to bright light in the morning and melatonin administration at sleep time, can thus be recommended.

The postulation of an association between motor fluctuations in $\mathrm{PD}$ and the diurnal variation in circulating melatonin levels relies on the existence of melatonin effects on striatal DA and serotonin content (Escames et al., 1996). In view that L-DOPArelated motor complications is seen in about $50 \%$ of PD patients after $5^{\circ}$ years of treatment, the results obtained in experimental parkinsonism warrant the use of melatonin to decrease L-DOPA doses in PD (Naskar et al., 2015).

In view that the stimulation of the globus pallidus ameliorated motor symptoms and complications in PD and inhibited the increase in diurnal plasma levels of melatonin the hypothesis was put forth that wearing-off episodes in PD could be related to the loss of the inhibitory motor effect of melatonin (Catalá et al., 1997). Relevant to the topic of the present review, epidemiological studies indicated that longer years of night work were associated with a reduced risk of $\mathrm{PD}$ and decreased levels of circulating melatonin (Bajaj et al., 2010).

PD patients showed a decreased density of MT1 and MT2 melatonin receptors in the substantia nigra and amygdala (Adi et al., 2010b) a finding that led to the assumption that an altered melatonergic system could underlie the altered sleep/wake cycle observed in PD. An increase in nighttime sleep was detected actigraphically in $40 \mathrm{PD}$ patients receiving a daily dose of $50 \mathrm{mg}$ melatonin at bedtime while those patients treated with $5 \mathrm{mg}$ of melatonin daily reported a significant improvement in subjective sleep assessment only (Dowling et al., 2005).

Medeiros and co-workers examined 18 parkinsonian patients who were randomized after a baseline polysomnography to receive melatonin $(3 \mathrm{mg})$ or placebo at bedtime for $4^{\circ}$ weeks (Medeiros et al., 2007). A significant improvement of sleep quality but no effect on motor dysfunction was found. A similar dissociation of effects of melatonin was reported in a double-blind, placebo, randomized study in $34 \mathrm{PD}$ patients (Ahn et al., 2020). The beneficial effects on sleep quality after melatonin were associated with improved non-motor symptoms and quality of life but not with amelioration of motor symptoms.

However, in another double-blind, placebo, randomized study, $10 \mathrm{mg}$ of melatonin to $60 \mathrm{PD}$ patients for $12^{\circ}$ weeks significantly 
TABLE 2 | Clinical trials with melatonin in Parkinson's disease.

\begin{tabular}{|c|c|c|c|c|c|c|}
\hline Ref & Sample & Design & Comparator & Duration & $\begin{array}{l}\text { Melatonin } \\
\text { treatment }\end{array}$ & Assessment \\
\hline $\begin{array}{l}\text { Dowling et al. } \\
\text { (2005) }\end{array}$ & 40 PD & Open-label & Placebo & 2 weeks & $\begin{array}{l}5-50 \mathrm{mg} / \text { day at } \\
\text { bedtime, p.o }\end{array}$ & Actigraphy \\
\hline $\begin{array}{l}\text { Medeiros et al. } \\
(2007)\end{array}$ & 18 PD & Open-label & Placebo & 4 weeks & $\begin{array}{l}3 \text { mg/day at } \\
\text { bedtime, p.o }\end{array}$ & PSG, PSQI, and ESS \\
\hline
\end{tabular}

\begin{tabular}{|c|c|c|c|c|c|c|c|}
\hline $\begin{array}{l}\text { Litvinenko et al. } \\
\text { (2012) }\end{array}$ & $\begin{array}{l}38 \text { PD (no } \\
\text { dementia, self- } \\
\text { reported sleep } \\
\text { disorders) }\end{array}$ & Open-label & $\begin{array}{l}\text { Clonazepam } \\
2 \mathrm{mg}\end{array}$ & 6 weeks & $\begin{array}{l}3 \mathrm{mg} / \text { day at } \\
\text { bedtime, p.o }\end{array}$ & $\begin{array}{l}\text { PSG, PDSS, } \\
\text { Neuropsychological testing } \\
\text { (MMSE, five-word test, digit } \\
\text { span and the Hamilton scale) }\end{array}$ & $\begin{array}{l}\text { sleep was also improved } \\
\text { Melatonin had a greater effect } \\
\text { on sleep disorders compared } \\
\text { to clonazepam. Patients } \\
\text { treated with melatonin had } \\
\text { better scores on the MMSE, } \\
\text { five-word test, and the } \\
\text { Hamilton scale at the end of } \\
\text { the study }\end{array}$ \\
\hline Ortiz et al. (2017) & 13 PD & $\begin{array}{l}\text { Double-blind, } \\
\text { randomized }\end{array}$ & Placebo & 12 months & $\begin{array}{l}25 \text { mg every } \\
12 \text { h, p.o }\end{array}$ & $\begin{array}{l}\text { UPDRS. Measurement of. COX- } \\
2 \text { activity and markers of } \\
\text { antioxidants activity }\end{array}$ & $\begin{array}{l}\text { Melatonin decreased COX-2 } \\
\text { activity and improved some } \\
\text { antioxidant markers. UPDRS } \\
\text { score decreased in the } \\
\text { melatonin-treated patients } \\
\text { but no in the placebo group }\end{array}$ \\
\hline $\begin{array}{l}\text { Daneshvar } \\
\text { Kakhaki et al. } \\
(2020)\end{array}$ & $60 \mathrm{PD}$ & $\begin{array}{l}\text { Double-blind, } \\
\text { randomized }\end{array}$ & Placebo & 12 weeks & $\begin{array}{l}10 \mathrm{mg} / \text { day at } \\
\text { bedtime, p.o }\end{array}$ & $\begin{array}{l}\text { UPDRS, PSQI, BDI, Bai. Markers } \\
\text { of antioxidant activity, } \\
\text { inflammatory response, and } \\
\text { hormonal status were also } \\
\text { measured }\end{array}$ & $\begin{array}{l}\text { Melatonin supplementation } \\
\text { significantly reduced UPDRS } \\
\text { part I score, PSQI, BDI and } \\
\text { Bai. It also resulted in an } \\
\text { increase in antioxidant } \\
\text { capacity, and reduced serum } \\
\text { insulin levels, HOMA-IR, total } \\
\text { and LDL-cholesterol as well } \\
\text { as gene expression of TNF- } \alpha \text {, } \\
\text { PPAR- } \gamma \text { and LDLR. }\end{array}$ \\
\hline Ahn et al. (2020) & $\begin{array}{l}34 \text { PD (poor } \\
\text { sleep quality) }\end{array}$ & $\begin{array}{l}\text { Double-blind, } \\
\text { randomized }\end{array}$ & Placebo & 4 weeks & $\begin{array}{l}2 \text { mg prolonged } \\
\text { release } \\
\text { melatonin } \\
\left(\text { Circadin }^{\mathrm{R}}\right) \text { at } \\
\text { bedtime }\end{array}$ & $\begin{array}{l}\text { PSQI, RBDSQ, the ESS, NMSS, } \\
\text { PDQ-39, and UPDRS-III }\end{array}$ & $\begin{array}{l}\text { Melatonin treatment was } \\
\text { associated with } \\
\text { improvements in PSQI, } \\
\text { NMSS and PDQ-39. No } \\
\text { changes were observed in } \\
\text { UPDRS-III. }\end{array}$ \\
\hline $\begin{array}{l}\text { Delgado-Lara } \\
\text { et al. (2020) }\end{array}$ & $26 \mathrm{PD}$ & $\begin{array}{l}\text { Double-blind, } \\
\text { randomized }\end{array}$ & Placebo & 3 months & $\begin{array}{l}25 \mathrm{mg} / \text { day at } \\
\text { bedtime, p.o }\end{array}$ & $\begin{array}{l}\text { ESS, SCOPA-sleep, UPDRS } \\
\text { and Hoehn and Yahr scale. } \\
\text { Relative expression of the PER1 } \\
\text { and BMAL1 genes (RT-qPCR) }\end{array}$ & $\begin{array}{l}\text { Melatonin increasing BMAL1 } \\
\text { expression but did not } \\
\text { improved sleep parameters }\end{array}$ \\
\hline
\end{tabular}

p.o.: oral administration; $P S G$ = polysomnography; $P S Q I=$ pittsburgh sleep quality index; $E S S=$ epworth sleepiness scale; $P D S S=P D$ sleep scale; UPDRS = unified parkinson's disease rating Scale; $C O X-2$ = ciclooxigenase two; $B D I$ = beck depression Inventory; $B A I=$ beck anxiety inventory; HOMA-IR = homeostatic model assessment for insulin resistance; $R B D S Q=$ rapid eye movement sleep behavior disorder screening questionnaire; NMSS = non-motor symptoms scale; PDQ-39 = Parkinson's disease quality of life-39.

normalized Unified Parkinson's disease Rating Scale part I score, PSQI, Beck Depression and Anxiety Inventories, and plasma levels of C-reactive protein, total antioxidant capacity, glutathione, LDLcholesterol, glucose and insulin (Daneshvar Kakhaki et al., 2020). Gene expression of TNF- $\alpha$, PPAR- $\gamma$ and LDLR was also corrected by melatonin. In partial agreement with this last study, UPDRS score decreased as well as COX-2 activity, nitrates/nitrites and lipoperoxides in melatonin-treated PD patients $(25 \mathrm{mg}$ every 12 h) (Ortiz et al., 2017).
A reduction of stiffness and bradykinesia, agitation and psychiatric side effects were reported in parkinsonian patients exposed to $1-1.5 \mathrm{~h}$ of light (1000-1500 lux) before bedtime, the authors concluding that decreased melatonin levels could be of therapeutic value in PD (Willis and Turner, 2007). However, as shown in depressive patients undergoing phototherapy, the inhibition of melatonin release is not the likely mechanism by which artificial light exerts its therapeutic effect (Lewy et al., 1984). Collectively, the 


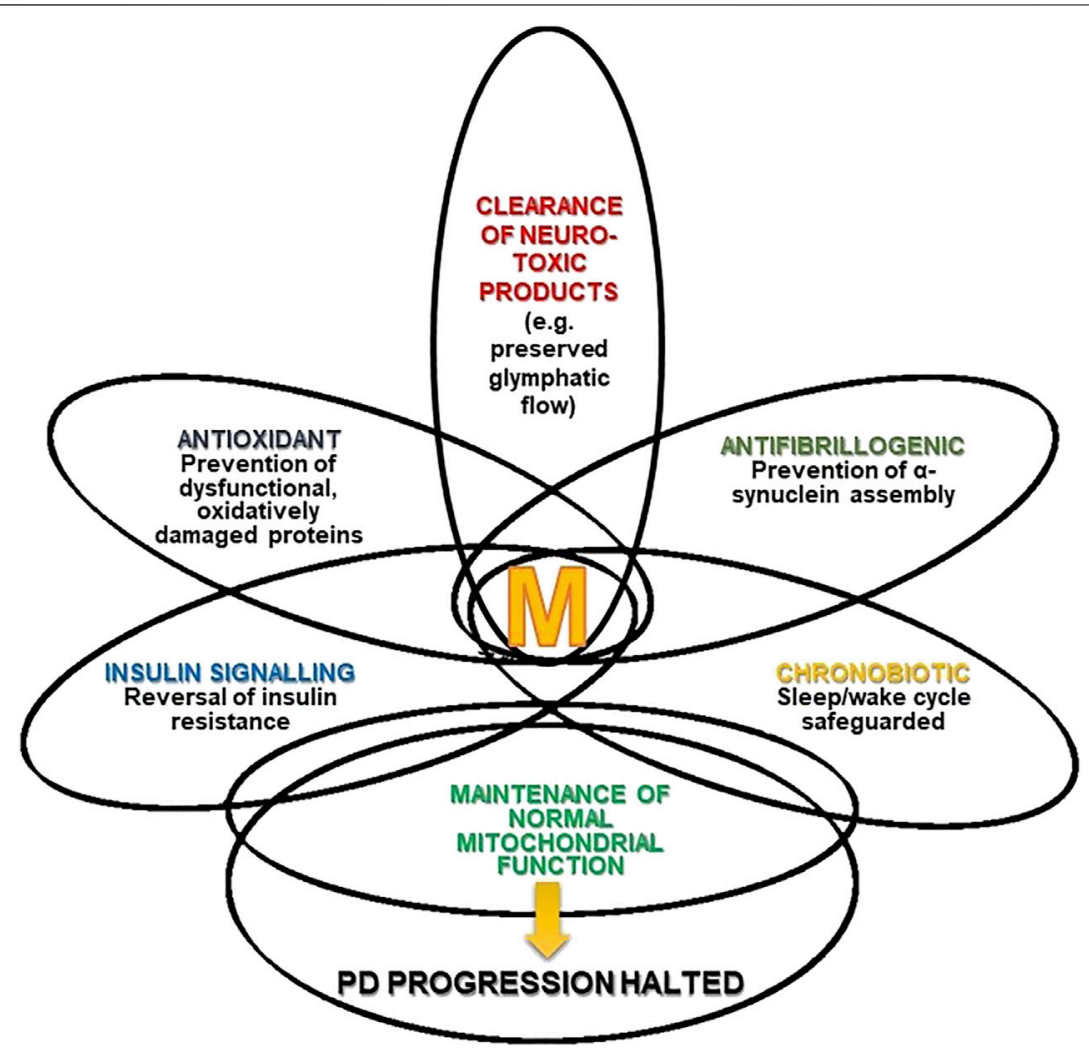

FIGURE 1 | Melatonin (M) and Parkinson's disease (PD). The Figure depicts the multiple effects of melatonin and the different degree of overlap (interrelations and mutual influences) they have.

gathered information points out to the circadian apparatus as an important diagnostic and therapeutic tool in PD (Willis and Freelance, 2018). A summary of clinical trials with melatonin in PD is offered in Table 2.

Table 3 summarizes the clinical studies reporting on the use of melatonin in RBD. Non-motor symptoms such as RBD, hyposmia or depression precede the onset of $\mathrm{PD}$ by several years (Michel et al., 2016). RBD prevalence in PD amounts to $20-50 \%$ while in the general population is about $1 \%$. Patients with RBD, especially men $>50$ years of age, will convert to an a-synucleinopathy, with a mean interval for conversion from time of RBD onset of approximately $10^{\circ}$ years (Dauvilliers et al., 2018). As above discussed, sleep/wake cycle disturbances are common non-motor symptoms in PD and presumably reflect the more fundamental circadian pathology in parkinsonian patients.

As summarized in Table 3 the daily doses of melatonin effective to treat RBD ranged from 3 to $12 \mathrm{mg}$ daily at bedtime. A decreased in movement time during REM sleep and in number of $\mathrm{R}$ epochs without atony were documented by polysomnography in RBD patients treated with melatonin; in contrast patients receiving clonazepam exhibited the persistence of muscle tone in REM sleep. Based on these results, a clinical consensus recommended the use of melatonin in RBD at level B (Aurora et al., 2010).
However, a negative result was recently published in a randomized, double-blind, placebo controlled, parallel-group trial of $30 \mathrm{RBD}$ patients treated unsuccessfully for $8^{\circ}$ weeks with $4 \mathrm{mg}$ prolonged release melatonin (Gilat et al., 2020). Therefore, more high-quality studies are needed in this respect.

In view of the high conversion rate of idiopathic $R B D$ to $P D$ several consensuses have stressed the necessity of studies looking for neuroprotection in $\mathrm{RBD}$. In fact, the rate of conversion to synucleinopathy in RBD patients treated with clonazepam is very high (Dauvilliers et al., 2018). Although comparable data are not yet available for RBD patients treated with melatonin, a case report deserves consideration (Kunz and Bes, 2018). In a 72-year-old male RBD patient treated with $2 \mathrm{mg}$ slow-release melatonin daily an increase in DA transporter density over successive years was documented. Moreover, the clinical and electrophysiologic signs of $\mathrm{RBD}$ disappeared after $6^{\circ}$ months. In addition, no signs of PD were present $4^{\circ}$ years after the first examination, indicating the possible neuroprotective role for melatonin in synucleinopathy (Kunz and Bes, 2018).

Figure 1 summarizes the different mechanisms by which melatonin can stop the progression of PD. The intersections in the Figure represent the multiple effects of melatonin and the different degrees of overlap (interrelationships and mutual influences) discussed in this review article. 
TABLE 3 | Studies including RBD patients with melatonin.

\begin{tabular}{|c|c|c|c|c|c|c|}
\hline Ref & $\begin{array}{c}\mathrm{Nb} \text { of } \\
\text { RBD patients }\end{array}$ & Design & $\begin{array}{l}\text { Study's } \\
\text { duration }\end{array}$ & $\begin{array}{l}\text { Melatonin } \\
\text { treatments }\end{array}$ & Measured & Results \\
\hline $\begin{array}{l}\text { Kunz and Bes, } \\
\text { (1997) }\end{array}$ & 1 & Case report & 5 months & $\begin{array}{l}3 \text { mg/day at } \\
\text { bedtime, p.o }\end{array}$ & Actigraphy, PSG & $\begin{array}{l}\text { Significant reduction of motor } \\
\text { activity during sleep, as measured } \\
\text { by actigraphy. PSG showed an } \\
\text { increase of REM sleep }\end{array}$ \\
\hline $\begin{array}{l}\text { Kunz and Bes, } \\
\text { (1999) }\end{array}$ & 6 & Case series & 6 weeks & $\begin{array}{l}3 \mathrm{mg} / \text { day at } \\
\text { bedtime, p.o }\end{array}$ & PSG & $\begin{array}{l}\text { Significant PSG improvement in } 5 \\
\text { patients }\end{array}$ \\
\hline $\begin{array}{l}\text { Takeuchi et al. } \\
\text { (2001) }\end{array}$ & 14 & Case series & Variable & $\begin{array}{l}3-9 \mathrm{mg} / \text { day at } \\
\text { bedtime, p.o }\end{array}$ & PSG & $\begin{array}{l}13 \text { patients reported a no } \\
\text { problematic sleep behaviors after } \\
\text { melatonin administration. A } \\
\text { decrease in tonic REM activity after } \\
\text { melatonin administration was also } \\
\text { observed }\end{array}$ \\
\hline $\begin{array}{l}\text { Boeve et al. } \\
\text { (2003) }\end{array}$ & 14 & $\begin{array}{l}\text { Case series } \\
\text { (retrospective) }\end{array}$ & 14 months & $\begin{array}{l}\text { 3-12 mg/day at } \\
\text { bedtime, p.o }\end{array}$ & PSG & $\begin{array}{l}8 \text { patients experienced continued } \\
\text { benefit }\end{array}$ \\
\hline $\begin{array}{l}\text { Anderson and } \\
\text { Shneerson, } \\
\text { (2009) }\end{array}$ & 39 & $\begin{array}{l}\text { Case series } \\
\text { (retrospective) }\end{array}$ & & $\begin{array}{l}10 \mathrm{mg} / \text { day at } \\
\text { bedtime p.o }\end{array}$ & Medication use & $\begin{array}{l}\text { Two patients used melatonin } \\
(10 \mathrm{mg}) \text { and both found it effective }\end{array}$ \\
\hline $\begin{array}{l}\text { McCarter et al. } \\
\text { (2013) }\end{array}$ & 25 & $\begin{array}{l}\text { Case series } \\
\text { (retrospective) }\end{array}$ & 27-53 months & $\begin{array}{l}6 \mathrm{mg} / \mathrm{day} \text { at } \\
\text { bedtime, p.o }\end{array}$ & & $\begin{array}{l}\text { Melatonin users reported reduced } \\
\text { injuries and fewer adverse effects }\end{array}$ \\
\hline $\begin{array}{l}\text { Kunz and } \\
\text { Mahlberg, } \\
(2010)\end{array}$ & 8 & $\begin{array}{l}\text { Double blind, } \\
\text { randomized, } \\
\text { placebo-controlled }\end{array}$ & 4 weeks & $\begin{array}{l}3 \mathrm{mg} / \text { day at } \\
\text { bedtime, p.o }\end{array}$ & PSG & $\begin{array}{l}\text { Reduced REM without atonia and } \\
\text { frequency of RBD episodes }\end{array}$ \\
\hline $\begin{array}{l}\text { Kunz and Bes, } \\
\text { (2018) }\end{array}$ & 1 & Case report & 5 years & $\begin{array}{l}2 \mathrm{mg} / \text { day at } \\
\text { bedtime, p.o. } \\
\text { (prolonged release } \\
\text { formulation) }\end{array}$ & $\begin{array}{l}\text { PSG and DA transporter } \\
\text { scintigraphy (DaTSCAN) }\end{array}$ & $\begin{array}{l}\text { A 72-year-old man was clinically } \\
\text { suspected to suffer from PD in } \\
\text { 2011. PD and RBD diagnoses } \\
\text { were confirmed by DaTSCAN and } \\
\text { PSG. 6-months after melatonin } \\
\text { treatment, clinical signs of RBD } \\
\text { were absent. Control PSG in } 2014 \\
\text { confirmed normalized REM sleep } \\
\text { with atonia. DaTSCANs performed } \\
\text { in } 2013 \text { and } 2015 \text { indicated } \\
\text { normalization of DA transporter } \\
\text { density }\end{array}$ \\
\hline $\begin{array}{l}\text { Schaefer et al. } \\
(2017)\end{array}$ & $\begin{array}{c}4 \text { (with } \\
\text { concomitant } \\
\text { obstructive sleep } \\
\text { apnea) }\end{array}$ & Open label & 4 weeks & $\begin{array}{l}2 \mathrm{mg} / \text { day at } \\
\text { bedtime, p.o. } \\
\text { (prolonged release } \\
\text { formulation) }\end{array}$ & PSG & $\begin{array}{l}\text { Treatment led to a relevant clinical } \\
\text { improvement of RBD symptoms in } \\
\text { all patients }\end{array}$ \\
\hline $\begin{array}{l}\text { Gilat et al. } \\
(2020)\end{array}$ & 30 & $\begin{array}{l}\text { Double blind, } \\
\text { randomized, } \\
\text { placebo-controlled }\end{array}$ & 8 weeks & $\begin{array}{l}4 \mathrm{mg} \text { prolonged } \\
\text { release melatonin } \\
\text { p.o./daily at bed } \\
\text { time }\end{array}$ & $\begin{array}{l}\text { Aggregate of RBD incidents } \\
\text { averaged over weeks } 5-8 \text { of } \\
\text { treatment captured by a } \\
\text { weekly diary }\end{array}$ & $\begin{array}{l}\text { No differences between groups at } \\
\text { the primary endpoint }\end{array}$ \\
\hline
\end{tabular}

$R B D=R E M$ sleep behaviour disorder; $P S G=$ polysomnography

\section{CONCLUSION}

Due to the hypnotic and chronobiotic properties of melatonin, its use for the treatment of insomnia has been recommended. Several metaanalyses support such a therapeutic role (Auld et al., 2017; FerracioliOda et al., 2018; Li et al., 2019) Additionally, a number of consensuses concluded that melatonin is the first-line treatment when a hypnotic is indicated in patients over 55 years of age (Wilson et al., 2010; Geoffroy et al., 2019; Palagini et al., 2020; Vecchierini et al., 2020). However, as discussed in this article, clinical studies with $2-5 \mathrm{mg}$ melatonin/day may not be adequate to provide comparison with data on protection against neurodegeneration derived from animal studies. Indeed, studies with doses of $100 \mathrm{mg} /$ day or higher are needed. Melatonin may also be involved in the pathophysiology of other non-motor symptoms in PD, but the current evidence is not convincing enough (Li et al., 2020; Batla et al., 2021) Therefore, more research is needed.

The safety of melatonin is very high and its non-toxicity remarkable. The lethal dose 50 after intraperitoneal injection was $1168 \mathrm{mg} / \mathrm{kg}$ (rats) and $1131 \mathrm{mg} / \mathrm{kg}$ (mice) but could not be reached after oral administration of melatonin (tested up to $3200 \mathrm{mg} / \mathrm{kg}$ in rats or subcutaneous injection of melatonin (tested up to $1600 \mathrm{mg} / \mathrm{kg}$ in rats and mice) (Sugden, 1983). There is evidence in dose escalation, phase 1, experiments of the remarkable lack of toxicity of melatonin in humans up to $100 \mathrm{mg}$ (Galley et al., 2014; Andersen et al., 2016). As discussed elsewhere (Cardinali, 2019a), high doses of melatonin have been used in various pathologies without undesirable sequelae, that is, in humans, melatonin has a high safety profile and, in general, is 
very well tolerated. Currently, the only option for the incumbent physician interested in the use of melatonin as a cytoprotector is the off-label indication of the drug. Therefore, studies on the potential disease-modifying effects of melatonin are warranted. RBD patients may be the first group to target with melatonin. Indeed, melatonin has shown some interesting therapeutic effects in this group, although it must be remarked that highquality evidence is lacking. Therefore, two birds might be killed with the same tone, as melatonin would offer an immediate clinical benefit in addition to reducing the rate of conversion to PD.

\section{REFERENCES}

Abramov, A. Y., Potapova, E. V., Dremin, V. V., and Dunaev, A. V. (2020). Interaction of oxidative stress and misfolded proteins in the mechanism of neurodegeneration. Life. Basel. 10, 1-14. doi:10.3390/life10070101

Acuña-Castroviejo, D., Coto-Montes, A., Monti, M. G., Ortiz, G. G., and Reiter, R. J. (1996). Melatonin is protective against MPTP-induced striatal and hippocampal lesions. Life Sci. 60. doi:10.1016/s0024-3205(96)00606-6

Acuña-Castroviejo, D., Escames, G., Venegas, C., Díaz-Casado, M. E., LimaCabello, E., López, L. C., et al. (2014). Extrapineal melatonin: sources, regulation, and potential functions. Cell. Mol. Life Sci. 71, 2997-3025. doi:10.1007/s00018-014-1579-2

Adi, N., Mash, D. C., Ali, Y., Singer, C., Shehadeh, L., and Papapetropoulos, S. (2010a). Melatonin MT1 and MT2 receptor expression in Parkinson's disease. Med. Sci. Monit. 16. , 2010a Available at: https://pubmed.ncbi.nlm.nih.gov/ 20110911/ (Accessed September 19, 2020)

Adi, N., Mash, D. C., Ali, Y., Singer, C., Shehadeh, L., and Papapetropoulos, S. (2010b). Melatonin MT1 and MT2 receptor expression in Parkinson's disease. Med. Sci. Monit. 16, BR61-BR67.

Aguiar, L. M. V., Vasconcelos, S. M. M., Sousa, F. C. F., and Viana, G. S. B. (2002). Melatonin reverses neurochemical alterations induced by 6-OHDA in rat striatum. Life Sci. 70, 1041-1051. doi:10.1016/S0024-3205(01)01480-1

Ahn, J. H., Kim, M., Park, S., Jang, W., Park, J., Oh, E., et al. (2020). Prolongedrelease melatonin in Parkinson's disease patients with a poor sleep quality: a randomized trial. Park. Relat. Disord. 75, 50-54. doi:10.1016/j.parkreldis.2020. 03.029

Ahsan Ejaz, A., Sekhon, I. S., and Munjal, S. (2006). Characteristic findings on 24-h ambulatory blood pressure monitoring in a series of patients with Parkinson's disease. Eur. J. Intern. Med. 17, 417-420. doi:10.1016/j.ejim.2006.02.020

Amaral, F. G. Do., Andrade-Silva, J., Kuwabara, W. M. T., and Cipolla-Neto, J. (2019). New insights into the function of melatonin and its role in metabolic disturbances. Expert Rev. Endocrinol. Metab. 14, 293-300. doi:10.1080/ 17446651.2019.1631158

American Academy of Sleep Medicine (2015). The international classification of sleep disorders. Darien, IL, American Academy of Sleep Medicine

Ancoli-Israel, S., Kripke, D. F., Klauber, M. R., Mason, W. J., Fell, R., and Kaplan, O. (1991). Periodic limb movements in sleep in community-dwelling elderly. Sleep 14, 496-500. doi:10.1093/sleep/14.6.496

Andersen, L. P. H., Werner, M. U., Rosenkilde, M. M., Harpsøe, N. G., Fuglsang, H., Rosenberg, J., et al. (2016). Pharmacokinetics of oral and intravenous melatonin in healthy volunteers. BMC Pharmacol. Toxicol. 17. doi:10.1186/ s40360-016-0052-2

Anderson, K. N., and Shneerson, J. M. (2009). Drug treatment of REM sleep behavior disorder: the use of drug therapies other than clonazepam. J. Clin. Sleep Med. 5, 235-239. doi:10.5664/jcsm.27492

Athauda, D., and Foltynie, T. (2016). Insulin resistance and Parkinson's disease: a new target for disease modification?. Prog. Neurobiol. 145-146, 98-120. doi:10. 1016/j.pneurobio.2016.10.001

Auld, F., Maschauer, E. L., Morrison, I., Skene, D. J., and Riha, R. L. (2017). Evidence for the efficacy of melatonin in the treatment of primary adult sleep disorders. Sleep Med. Rev. 34, 10-22. doi:10.1016/j.smrv.2016.06.005

\section{AUTHOR CONTRIBUTIONS}

Conceptualization: SP-L. DC. Writing, Original draft: SP-L. DC. Writing, Review and Editing: SP-L. DC.

\section{ACKNOWLEDGMENTS}

SP-L is an independent investigator from CONICET. DC. is an Emeritus Superior Investigator from CONICET and Emeritus Professor, University of Buenos Aires.

Aurora, R. N., Zak, R. S., Maganti, R. K., Auerbach, S. H., Casey, K. R., Chowdhuri, S., et al. (2010). Best practice guide for the treatment of REM sleep behavior disorder (RBD). J. Clin. Sleep Med. 6, 85-95. doi:10.5664/jcsm.27717

Avidan, A., Hays, R. D., Diaz, N., Bordelon, Y., Thompson, A. W., Vassar, S. D., et al. (2013). Associations of sleep disturbance symptoms with health-related quality of life in Parkinson's disease. J. Neuropsychiatry Clin. Neurosci. 25, 319-326. doi:10.1176/appi.neuropsych.12070175

Aviles-Olmos, I., Limousin, P., Lees, A., and Foltynie, T. (2013). Parkinson's disease, insulin resistance and novel agents of neuroprotection. Brain 136, 374-384. doi:10.1093/brain/aws009

Azmin, S., Khairul Anuar, A. M., Nafisah, W. Y., Tan, H. J., Raymond, A. A. Hanita, O., et al. (2013). Restless legs syndrome and its associated risk factors in Parkinson's disease. Parkinsons. Dis. 2013, 535613. doi:10.1155/2013/535613

Bajaj, A., Driver, J. A., and Schernhammer, E. S. (2010). Parkinson's disease and cancer risk: a systematic review and meta-analysis. Cancer Causes Control 21, 697-707. doi:10.1007/s10552-009-9497-6

Barcia, C., De Pablos, V., Bautista-Hernández, V., Sanchez-Bahillo, A., FernándezBarreiro, A., Poza, M., et al. (2004). Measurement of motor disability in MPTPtreated macaques using a telemetry system for estimating circadian motor activity. J. Neurosci. Methods 134, 59-64. doi:10.1016/j.jneumeth.2003.10.017

Barker, R. A., and Björklund, A. (2020). Animal models of Parkinson's disease: are they useful or not? J. Parkinsons. Dis. 10, 1335-1342. doi:10.3233/jpd-202200

Bassani, T. B., Gradowski, R. W., Zaminelli, T., Barbiero, J. K., Santiago, R. M., Boschen, S. L., et al. (2014). Neuroprotective and antidepressant-like effects of melatonin in a rotenone-induced Parkinson's disease model in rats. Brain Res. 1593, 95-105. doi:10.1016/j.brainres.2014.09.068

Batla, A., Simeoni, S., Uchiyama, T., deMin, L., Baldwin, J., Melbourne, C., et al. (2021). Exploratory pilot study of exogenous sustained-release melatonin on nocturia in parkinson's disease. Eur. J. Neurol. 45. doi:10.1111/ene.14774

Belaid, H., Adrien, J., Karachi, C., Hirsch, E. C., and François, C. (2015). Effect of melatonin on sleep disorders in a monkey model of Parkinson's disease. Sleep Med. 16, 1245-1251. doi:10.1016/j.sleep.2015.06.018

Ben, V., and Bruguerolle, B. (2000). Effects of bilateral striatal 6-OHDA lesions on circadian rhythms in the rat A radiotelemetric study. Life Sci. 67, 1549-1558. doi:10.1016/S0024-3205(00)00751-7

Berganzo, K., Díez-Arrola, B., Tijero, B., Somme, J., Lezcano, E., Llorens, V., et al. (2013). Nocturnal hypertension and dysautonomia in patients with Parkinson's disease: are they related? J. Neurol. 260, 1752-1756. doi:10.1007/s00415-0136859-5

Boeve, B. F., Silber, M. H., and Ferman, T. J. (2003). Melatonin for treatment of REM sleep behavior disorder in neurologic disorders: results in 14 patients. Sleep Med. 4, 281-284. doi:10.1016/S1389-9457(03)00072-8

Boland, B., Yu, W. H., Corti, O., Mollereau, B., Henriques, A., Bezard, E., et al. (2018). Promoting the clearance of neurotoxic proteins in neurodegenerative disorders of ageing. Nat. Rev. Drug Discov. 17, 660-688. doi:10.1038/nrd. 2018.109

Bordet, R., Devos, D., Brique, S., Touitou, Y., Guieu, J. D., Libersa, C., et al. (2003). Study of circadian melatonin secretion pattern at different stages of Parkinson's disease. Clin. Neuropharmacol. 26, 65-72. doi:10.1097/00002826-200303000-00005

Boulamery, A., Simon, N., Vidal, J., and Bruguerolle, B. (2010). Effects of l-dopa on circadian rhythms of 6-ohda striatal lesioned rats: a radiotelemetric study. Chronobiol. Int. 27, 251-264. doi:10.3109/07420521003664213 
Breen, D. P., Vuono, R., Nawarathna, U., Fisher, K., Shneerson, J. M., Reddy, A. B., et al. (2014). Sleep and circadian rhythm regulation in early Parkinson disease. JAMA Neurol. 71, 589-595. doi:10.1001/jamaneurol.2014.65

Brito-Armas, J. M., Baekelandt, V., Castro-Hernández, J. R., González-Hernández, T., Rodríguez, M., and Fuentes, R. C. (2013). Melatonin prevents dopaminergic cell loss induced by lentiviral vectors expressing A30P mutant alpha-synuclein. Histol. Histopathol. 28, 999-1006. doi:10.14670/HH-28.999

Burton, S., Daya, S., and Potgieter, B. (1991). Melatonin modulates apomorphineinduced rotational behaviour. Experientia 47, 466-469. doi:10.1007/ BF01959946

Buskova, J., Klempir, J., Majerova, V., Picmausova, J., Onka, K. S., Jech, R., et al. (2011). Sleep disturbances in untreated Parkinson's disease. J. Neurol. 258, 2254-2259. doi:10.1007/s00415-011-6109-7

Buysse, D. J., Reynolds, C. F., Monk, T. H., Berman, S. R., and Kupfer, D. J. (1989). The Pittsburgh sleep quality index: a new instrument for psychiatric practice and research. Psychiatry Res. 28, 193-213. doi:10.1016/0165-1781(89)90047-4

Cai, Y., Liu, S., Sothern, R. B., Xu, S., and Chan, P. (2010). Expression of clock genes Perl and Bmall in total leukocytes in health and Parkinson's disease. Eur. J. Neurol. 17, 550-554. doi:10.1111/j.1468-1331.2009.02848.x

Calzetti, S., Angelini, M., Negrotti, A., Marchesi, E., and Goldoni, M. (2014). A long-term prospective follow-up study of incident RLS in the course of chronic DAergic therapy in newly diagnosed untreated patients with Parkinson's disease. J. Neural Transm. 121, 499-506. doi:10.1007/s00702-013-1132-8

Cardinali, D. P. (2019a). Are melatonin doses employed clinically adequate for melatonin-induced cytoprotection?. Melatonin Res. 2, 106-132. doi:10.32794/ $\operatorname{mr} 11250025$

Cardinali, D. P. (2019b). Melatonin: clinical perspectives in neurodegeneration. Front. Endocrinol. 10, 480. doi:10.3389/fendo.2019.00480

Cardinali, D. P., Pandi-Perumal, S. R., Srinivasan, V., Spence, D. W., and Trakht, I. (2008). Therapeutic potential of melatonin agonists. Expert Rev. Endocrinol. Metab. 3, 269-279. doi:10.1586/17446651.3.2.269

Cardinali, D. P., Ritta, M. N., Fuentes, A. M., Gimeno, M. F., and Gimeno, A. L. (1980). Prostaglandin E release by rat medial basal hypothalamus in vitro. Inhibition by melatonin at submicromolar concentrations. Eur. J. Pharmacol. 67, 151-153. doi:10.1016/0014-2999(80)90025-4

Carriere, C. H., Kang, N. H., and Niles, L. P. (2016). Chronic low-dose melatonin treatment maintains nigrostriatal integrity in an intrastriatal rotenone model of Parkinson's disease. Brain Res. 1633, 115-125. doi:10.1016/j.brainres.2015. 12.036

Carrillo-Vico, A., Lardone, P. J., Álvarez-Śnchez, N., Rodrĩguez-Rodrĩguez, A., and Guerrero, J. M. (2013). Melatonin: buffering the immune system. Int. J. Mol. Sci. 14, 8638-8683. doi:10.3390/ijms14048638

Catalá, M. D., Cañete-Nicolás, C., Iradi, A., Tarazona, F. J., Tormos, J. M., and Pascual-Leone, A. (1997). Melatonin levels in Parkinson's disease: drug therapy versus electrical stimulation of the internal globus pallidus. Exp. Gerontol. 32, 553-558. doi:10.1016/S0531-5565(96)00173-8

Caumo, W., Levandovski, R., and Hidalgo, M. P. L. (2009). Preoperative anxiolytic effect of melatonin and clonidine on postoperative pain and morphine consumption in patients undergoing abdominal hysterectomy: a doubleblind, randomized, placebo-controlled study. J. Pain 10, 100-108. doi:10. 1016/j.jpain.2008.08.007

Cecon, E., Oishi, A., and Jockers, R. (2018). Melatonin receptors: molecular pharmacology and signalling in the context of system bias. Br. J. Pharmacol. 175, 3263-3280. doi:10.1111/bph.13950

Chahine, L. M., Amara, A. W., and Videnovic, A. (2017). A systematic review of the literature on disorders of sleep and wakefulness in Parkinson's disease from 2005 to 2015. Sleep Med. Rev. 35, 33-50. doi:10.1016/j.smrv. 2016.08.001

Chang, C. F., Huang, H. J., Lee, H. C., Hung, K. C., Wu, R. T., and Lin, A. M. Y. (2012). Melatonin attenuates kainic acid-induced neurotoxicity in mouse hippocampus via inhibition of autophagy and $\alpha$-synuclein aggregation. J. Pineal Res. 52, 312-321. doi:10.1111/j.1600-079X.2011.00945.x

Chaudhuri, K. R., Pal, S., DiMarco, A., Whately-Smith, C., Bridgman, K., Mathew, R., et al. (2002). The Parkinson's disease sleep scale: a new instrument for assessing sleep and nocturnal disability in Parkinson's disease. J. Neurol. Neurosurg. Psychiatry 73, 629-635. doi:10.1136/jnnp.73.6.629

Chen, S. T., Chuang, J. I., Hong, M. H., and Li, E. I. C. (2002). Melatonin attenuates $\mathrm{MPP}+$-induced neurodegeneration and glutathione impairment in the nigrostriatal dopaminergic pathway. J. Pineal Res. 32, 262-269. doi:10.1034/ j.1600-079X.2002.01871.x

Cheng, H. C., Ulane, C. M., and Burke, R. E. (2010). Clinical progression in Parkinson disease and the neurobiology of axons. Ann. Neurol. 67, 715-725. doi:10.1002/ana.21995

Cheng, X. P., Sun, H., Ye, Z. Y., and Zhou, J. N. (2012). Melatonin modulates the GABAergic response in cultured rat hippocampal neurons. J. Pharmacol. Sci. 119, 177-185. doi:10.1254/jphs.11183FP

Cho, S., Joh, T. H., Baik, H. H., Dibinis, C., and Volpe, B. T. (1997). Melatonin administration protects CA1 hippocampal neurons after transient forebrain ischemia in rats. Brain Res. 755, 335-338. doi:10.1016/S00068993(97)00188-1

Claustrat, B., and Leston, J. (2015). Melatonin: physiological effects in humans. Neurochirurgie 61, 77-84. doi:10.1016/j.neuchi.2015.03.002

Dabbeni-Sala, F., Santo, S., Franceschini, D., D. Skaper, S., and Pietro Giusti, A. (2001). Melatonin protects against 6-OHDA-induced neurotoxicity in rats: a role for mitochondrial complex I activity. FASEB J. 15, 164-170. doi:10.1096/fj. 00-0129com

Daneshvar Kakhaki, R., Ostadmohammadi, V., Kouchaki, E., Aghadavod, E., Bahmani, F., Tamtaji, O. R., et al. (2020). Melatonin supplementation and the effects on clinical and metabolic status in Parkinson's disease: a randomized, double-blind, placebo-controlled trial. Clin. Neurol. Neurosurg. 195, 105878. doi:10.1016/j.clineuro.2020.105878

Dauvilliers, Y., Schenck, C. H., Postuma, R. B., Iranzo, A., Luppi, P. H., Plazzi, G., et al. (2018). REM sleep behaviour disorder. Nat. Rev. Dis. Prim. 4, 19. doi:10. 1038/s41572-018-0016-5

Davies, J. M. S., Cillard, J., Friguet, B., Cadenas, E., Cadet, J., Cayce, R., et al. (2017). The oxygen paradox, the French paradox, and age-related diseases. GeroScience 39, 499-550. doi:10.1007/s11357-017-0002-y

Dawson, D., and Armstrong, S. M. (1996). Chronobiotics - drugs that shift rhythms. Pharmacol. Ther. 69, 15-36. doi:10.1016/0163-7258(95)02020-9

De Cock, V. C., Bayard, S., Yu, H., Grini, M., Carlander, B., Postuma, R., et al. (2012). Suggested immobilization test for diagnosis of restless legs syndrome in Parkinson's disease. Mov. Disord. 27, 743-749. doi:10.1002/mds.24969

De Pablo-Fernandez, E., Goldacre, R., Pakpoor, J., Noyce, A. J., and Warner, T. T. (2018). Association between diabetes and subsequent Parkinson disease: a record-linkage cohort study. Neurology 91, e139-e142. doi:10.1212/WNL. 0000000000005771

Delgado-Lara, D. L., González-Enríquez, G. V., Torres-Mendoza, B. M., GonzálezUsigli, H., Cárdenas-Bedoya, J., Macías-Islas, M. A., et al. (2020). Effect of melatonin administration on the PER1 and BMAL1 clock genes in patients with Parkinson's disease. Biomed. Pharmacother. 129, 110485. doi:10.1016/j.biopha.2020.110485

Deng, W. G., Tang, S. T., Tseng, H. P., and Wu, K. K. (2006). Melatonin suppresses macrophage cyclooxygenase- 2 and inducible nitric oxide synthase expression by inhibiting p52 acetylation and binding. Blood 108, 518-524. doi:10.1182/ blood-2005-09-3691

Ding, H., Liu, S., Yuan, Y., Lin, Q., Chan, P., and Cai, Y. (2011). Decreased expression of Bmal2 in patients with Parkinson's disease. Neurosci. Lett. 499, 186-188. doi:10.1016/j.neulet.2011.05.058

Dowling, G. A., Mastick, J., Colling, E., Carter, J. H., Singer, C. M., and Aminoff, M. J. (2005). Melatonin for sleep disturbances in Parkinson's disease. Sleep Med. 6, 459-466. doi:10.1016/j.sleep.2005.04.004

Dubocovich, M. L., Delagrange, P., Krause, D. N., Sugden, D., Cardinali, D. P., and Olcese, J. (2010). International union of basic and clinical pharmacology. LXXV. Nomenclature, classification, and pharmacology of G proteincoupled melatonin receptors. Pharmacol. Rev. 62, 343-380. doi:10.1124/pr. 110.002832

Escames, G., Castroviejo, D. A., and Vives, F. (1996). Melatonin-dopamine interaction in the striatal projection area of sensorimotor cortex in the rat. Neuroreport 7, 597-600. doi:10.1097/00001756-199601310-00053

Escames, G., León, J., López, L. C., and Acuña-Castroviejo, D. (2004). Mechanisms of N-methyl-D-aspartate receptor inhibition by melatonin in the rat striatum. J. Neuroendocrinol. 16, 929-935. doi:10.1111/j.1365-2826.2004.01250.x

Ferracioli-Oda, E., Qawasmi, A., and Bloch, M. H. (2018). Meta-Analysis: melatonin for the treatment of primary sleep disorders. Focus (Madison) 16, 113-118. doi:10.1176/appi.focus.16101

Fertl, E., Auff, E., Doppelbauer, A., and Waldhauser, F. (1993). Circadian secretion pattern of melatonin in de novo Parkinsonian patients: evidence for phase- 
shifting properties of 1-dopa. J. Neural Transm. - Park. Dis. Dement. Sect. 5, 227-234. doi:10.1007/BF02257677

Fifel, K., and Cooper, H. M. (2014). Loss of dopamine disrupts circadian rhythms in a mouse model of Parkinson's disease. Neurobiol. Dis. 71, 359-369. doi:10. 1016/j.nbd.2014.08.024

Fifel, K., Vezoli, J., Dzahini, K., Claustrat, B., Leviel, V., Kennedy, H., et al. (2014). Alteration of daily and circadian rhythms following dopamine depletion in MPTP treated non-human primates. PLoS One 9, e86240. doi:10.1371/journal. pone. 0086240

Furio, A. M., Fontao, R., Falco, N., Ruiz, J. I., Caccuri, R., and Cardinali, D. P. (2014). Neuroprotective effect of melatonin on glucocorticoid toxicity in the rat hippocampus. Open Physiol. J. 1, 23-27. doi:10.2174/1874360900901010023

Gallagher, D. A., Lees, A. J., and Schrag, A. (2010). What are the most important nonmotor symptoms in patients with Parkinson's disease and are we missing them?. Mov. Disord. 25, 2493-2500. doi:10.1002/mds.23394

Galley, H. F., Lowes, D. A., Allen, L., Cameron, G., Aucott, L. S., and Webster, N. R. (2014). Melatonin as a potential therapy for sepsis: a phase i dose escalation study and an ex vivo whole blood model under conditions of sepsis. J. Pineal Res. 56, 427-438. doi:10.1111/jpi.12134

Geoffroy, P. A., Micoulaud Franchi, J. A., Lopez, R., and Schroder, C. M. (2019). The use of melatonin in adult psychiatric disorders: expert recommendations by the French institute of medical research on sleep (SFRMS). Encephale 45, 413-423. doi:10.1016/j.encep.2019.04.068

Gilat, M., Coeytaux Jackson, A., Marshall, N. S., Hammond, D., Mullins, A. E., Hall, J. M., et al. (2020). Melatonin for rapid eye movement sleep behavior disorder in Parkinson's disease: a randomised controlled trial. Mov. Disord. 35, 344-349. doi:10.1002/mds.27886

Giusti, P., Upartiti, M., Franceschini, D., Schiavo, N., Floreani, M., and Manev, H. (1996). Neuroprotection by melatonin from kainate-induced excitotoxicity in rats. FASEB J. 10, 891-896. doi:10.1096/fasebj.10.8.8666166

Gjerstad, M. D., Wentzel-Larsen, T., Aarsland, D., and Larsen, J. P. (2007). Insomnia in Parkinson's disease: frequency and progression over time. J. Neurol. Neurosurg. Psychiatry 78, 476-479. doi:10.1136/jnnp.2006.100370

Golombek, D. A., PéVet, P., and Cardinali, D. P. (1996). Melatonin effects on behavior: possible mediation by the central GABAergic system. Neurosci. Biobehav. Rev. 20, 403-412. doi:10.1016/0149-7634(95)00052-6

Gómez-Esteban, J. C., Zarranz, J. J., Lezcano, E., Velasco, F., Ciordia, R., Rouco, I., et al. (2006). Sleep complaints and their relation with drug treatment in patients suffering from Parkinson's disease. Mov. Disord. 21, 983-988. doi:10.1002/mds. 20874

Gutierrez-Valdez, A. L., Anaya-Martínez, V., Ordoñez-Librado, J. L., García-Ruiz, R., Torres-Esquivel, C., Moreno-Rivera, M., et al. (2012). Effect of chronic L-dopa or melatonin treatments after dopamine deafferentation in rats: dyskinesia, motor performance, and cytological analysis. ISRN Neurol. 2012, 1-16. doi:10.5402/2012/360379

Hagell, P., and Broman, J. E. (2007). Measurement properties and hierarchical item structure of the Epworth sleepiness scale in Parkinson's disease. J. Sleep Res. 16, 102-109. doi:10.1111/j.1365-2869.2007.00570.x

Hardeland, R., Cardinali, D. P., Srinivasan, V., Spence, D. W., Brown, G. M., and Pandi-Perumal, S. R. (2011). Melatonin-A pleiotropic, orchestrating regulator molecule. Prog. Neurobiol. 93, 350-384. doi:10.1016/j.pneurobio.2010.12.004

Hardeland, R. (2018a). Melatonin and inflammation-story of a double-edged blade. J. Pineal Res. 65, e12525. doi:10.1111/jpi.12525

Hardeland, R. (2018b). Recent findings in melatonin research and their relevance to the CNS. Cent. Nerv. Syst. Agents Med. Chem. 18, 102-114. doi:10.2174/ 1871524918666180531083944

Hartmann, A., Veldhuis, J. D., Deuschle, M., Standhardt, H., and Heuser, I. (1997). Twenty-four hour cortisol release profiles in patients with Alzheimer's and Parkinson's disease compared to normal controls: ultrladian secretory pulsatility and diurnal variation. Neurobiol. Aging 18, 285-289. doi:10.1016/ S0197-4580(97)80309-0

Henderson, J. M., Slack, K., Billing, R., Matthews, S., Allbutt, H. N., and Einstein, R. (2010). Subtle cardiovascular dysfunction in the unilateral 6hydroxydopamine- lesioned rat. Parkinsons. Dis. 2010, 427810. doi:10.4061/ $2010 / 427810$

Högl, B., Arnulf, I., Comella, C., Ferreira, J., Iranzo, A., Tilley, B., et al. (2010). Scales to assess sleep impairment in Parkinson's disease: critique and recommendations. Mov. Disord. 25, 2704-2716. doi:10.1002/mds.23190
Hood, S., Cassidy, P., Cossette, M. P., Weigl, Y., Verwey, M., Robinson, B., et al. (2010). Endogenous dopamine regulates the rhythm of expression of the clock protein PER2 in the rat dorsal striatum via daily activation of D2 dopamine receptors. J. Neurosci. 30, 14046-14058. doi:10.1523/JNEUROSCI.2128-10. 2010

Horvath, I., and Wittung-Stafshede, P. (2016). Cross-talk between amyloidogenic proteins in type-2 diabetes and Parkinson's disease. Proc. Natl. Acad. Sci. U. S. A. 113, 12473-12477. doi:10.1073/pnas.1610371113

Hoshi, A., Tsunoda, A., Tada, M., Nishizawa, M., Ugawa, Y., and Kakita, A. (2017). Expression of aquaporin 1 and aquaporin 4 in the temporal neocortex of patients with Parkinson's disease. Brain Pathol. 27, 160-168. doi:10.1111/bpa. 12369

Huang, J. Y., Hong, Y. T., and Chuang, J. I. (2009). Fibroblast growth factor 9 prevents MPP+-induced death of dopaminergic neurons and is involved in melatonin neuroprotection in vivo and in vitro. J. Neurochem. 109, 1400-1412. doi:10.1111/j.1471-4159.2009.06061.x

Huang, L., Ren, Y., Zeng, Z., Ren, H., Li, S., He, S., et al. (2019). Comparative study of striatum GABA concentrations and magnetic resonance spectroscopic imaging in Parkinson's disease monkeys. BMC Neurosci. 20, 42. doi:10. 1186/s12868-019-0522-8

Huang, Q., and Riviere, J. E. (2014). The application of allometric scaling principles to predict pharmacokinetic parameters across species. Expert Opin. Drug Metab. Toxicol. 10, 1241-1253. doi:10.1517/17425255.2014.934671

Jiménez-Rubio, G., Ortíz-López, L., and Benítez-King, G. (2012). Melatonin modulates cytoskeletal organization in the rat brain hippocampus. Neurosci. Lett. 511, 47-51. doi:10.1016/j.neulet.2012.01.040

Jin, B. K., Shin, D. Y., Jeong, M. Y., Gwag, M. R., Baik, H. W., Yoon, K. S., et al. (1998). Melatonin protects nigral dopaminergic neurons from 1-methyl-4phenylpyridinium (MPP+) neurotoxicity in rats. Neurosci. Lett. 245, 61-64. doi:10.1016/S0304-3940(98)00170-0

Joo, W. S., Jin, B. K., Park, C. W., Maeng, S. H., and Kim, Y. S. (1998). Melatonin increases striatal dopaminergic function in 6-OHDA-lesioned rats. Neuroreport 9, 4123-4126. doi:10.1097/00001756-199812210-00022

Kam, T. I., Hinkle, J. T., Dawson, T. M., and Dawson, V. L. (2020). Microglia and astrocyte dysfunction in Parkinson's disease. Neurobiol. Dis. 144, 105028. doi:10.1016/j.nbd.2020.105028

Khaldy, H., Escames, G., León, J., Bikjdaouene, L., and Acuña-Castroviejo, D. (2003). Synergistic effects of melatonin and deprenyl against MPTP-induced mitochondrial damage and DA depletion. Neurobiol. Aging 24, 491-500. doi:10. 1016/S0197-4580(02)00133-1

Kim, Y. S., Joo, W. S., Jin, B. K., Cho, Y. H., Baik, H. H., and Park, C. W. (1998). Melatonin protects 6-OHDA-induced neuronal death of nigrostriatal dopaminergic system. Neuroreport 9, 2387-2390. doi:10.1097/00001756199807130-00043

Kudo, T., Loh, D. H., Truong, D., Wu, Y., and Colwell, C. S. (2011). Circadian dysfunction in a mouse model of Parkinson's disease. Exp. Neurol. 232, 66-75. doi:10.1016/j.expneurol.2011.08.003

Kunz, D., and Bes, F. (1999). Melatonin as a therapy in REM sleep behavior disorder patients: an open-labeled pilot study on the possible influence of melatonin on REM-sleep regulation. Mov. Disord. 14, 507-511. doi:10.1002/ 1531-8257(199905)14:3<507::AID-MDS1021>3.0.CO;2-8

Kunz, D., and Bes, F. (1997). Melatonin effects in a patient with severe REM sleep behavior disorder: case report and theoretical considerations. Neuropsychobiology 36, 211-214. doi:10.1159/000119383

Kunz, D., and Bes, F. (2018). Twenty years after: another case report of melatonin effects on REM sleep behavior disorder, using serial dopamine transporter imaging. Neuropsychobiology 76, 100-104. doi:10.1159/000488893

Kunz, D., and Mahlberg, R. (2010). A two-part, double-blind, placebo-controlled trial of exogenous melatonin in REM sleep behaviour disorder. J. Sleep Res. 19, 591-596. doi:10.1111/j.1365-2869.2010.00848.x

Lavie, P. (1997). Melatonin: role in gating nocturnal rise in sleep propensity. J. Biol. Rhythms 12, 657-665. doi:10.1177/074873049701200622

Lax, P., Esquiva, G., Esteve-Rudd, J., Otalora, B. B., Madrid, J. A., and Cuenca, N. (2012). Circadian dysfunction in a rotenone-induced parkinsonian rodent model. Chronobiol. Int. 29, 147-156. doi:10.3109/07420528.2011. 649870

Leeboonngam, T., Pramong, R., Sae-ung, K., Govitrapong, P., and PhansuwanPujito, P. (2018). Neuroprotective effects of melatonin on amphetamine- 
induced dopaminergic fiber degeneration in the hippocampus of postnatal rats. J. Pineal Res. 64. doi:10.1111/jpi.12456

Leng, A., Mura, A., Hengerer, B., Feldon, J., and Ferger, B. (2004). Effects of blocking the dopamine biosynthesis and of neurotoxic dopamine depletion with 1-methyl-4-phenyl-1,2,3,6-tetrahydropyridine (MPTP) on voluntary wheel running in mice. Behav. Brain Res. 154, 375-383. doi:10.1016/j.bbr. 2004.03.004

Lewy, A., Emens, J., Jackman, A., and Yuhas, K. (2006). Circadian uses of melatonin in humans. Chronobiol Int. 23, 403-412. doi:10.1080/ 07420520500545862

Lewy, A. J., Sack, R. A., and Singer, C. L. (1984). Assessment and treatment of chronobiologic disorders using plasma melatonin levels and bright light exposure: the clock-gate model and the phase response curve. Psychopharmacol. Bull. 20, 561-565. Available at: https://ohsu.pure.elsevier. $\mathrm{com} /$ en/publications/assessment-and-treatment-of-chronobiologic-disordersusing-plasma-2. (Accessed September 20, 2020)

Li, L., Zhao, Z., Ma, J., Zheng, J., Huang, S., Hu, S., et al. (2020). Elevated plasma melatonin levels are correlated with the non-motor symptoms in Parkinson's disease: a cross-sectional study. Front. Neurosci. 14, 505. doi:10.3389/fnins. 2020.00505

Li, T., Jiang, S., Han, M., Yang, Z., Lv, J., Deng, C., et al. (2019). Exogenous melatonin as a treatment for secondary sleep disorders: a systematic review and meta-analysis. Front. Neuroendocrinol. 52, 22-28. doi:10.1016/j.yfrne.2018. 06.004

Li, Y., Wang, S. M., Guo, L., Zhu, J., Wang, Y., Li, L., et al. (2017). Effects of melatonin levels on neurotoxicity of the medial prefrontal cortex in a rat model of Parkinson's disease. Chin. Med. J. (Engl). 130, 2726-2731. doi:10.4103/03666999.218025

Lin, A. M. Y., Fang, S. F., Chao, P. L., and Yang, C. H. (2007). Melatonin attenuates arsenite-induced apoptosis in rat brain: involvement of mitochondrial and endoplasmic reticulum pathways and aggregation of $\alpha$-synuclein. J. Pineal Res. 43, 163-171. doi:10.1111/j.1600-079X.2007.00456.x

Litvinenko, I. V., Krasakov, I. V., and Tikhomirova, O. V. (2012). [Sleep disorders in Parkinson's disease without dementia: a comparative randomized controlled study of melatonin and clonazepam]. Zh. Nevrol. Psikhiatr. Im. S. S. Korsakova 112, 26-30. Available at: https://pubmed.ncbi.nlm.nih.gov/23388588/. (Accessed September 8, 2020)

Loo, H. V., and Tan, E. K. (2008). Case-control study of restless legs syndrome and quality of sleep in Parkinson's disease. J. Neurol. Sci. 266, 145-149. doi:10.1016/ j.jns.2007.09.033

López, A., Ortiz, F., Doerrier, C., Venegas, C., Fernández-Ortiz, M., Aranda, P., et al. (2017). Mitochondrial impairment and melatonin protection in parkinsonian mice do not depend of inducible or neuronal nitric oxide synthases. PLoS One 12, e0183090. doi:10.1371/journal.pone.0183090

Louzada, P. R., Lima, A. C. P., Mendonca-Silva, D. L., Noël, F., De Mello, F. G., and Ferreira, S. T. (2004). Taurine prevents the neurotoxicity of $\beta$-amyloid and glutamate receptor agonists: activation of GABA receptors and possible implications for Alzheimer's disease and other neurological disorders. FASEB J. 18, 511-518. doi:10.1096/fi.03-0739com

Lozovaya, N., Eftekhari, S., Cloarec, R., Gouty-Colomer, L. A., Dufour, A., Riffault, B., et al. (2018). GABAergic inhibition in dual-transmission cholinergic and GABAergic striatal interneurons is abolished in Parkinson disease. Nat. Commun. 9, 1422. doi:10.1038/s41467-018-03802-y

Marinus, J., Visser, M., Van Hilten, J. J., Lammers, G. J., and Stiggelbout, A. M. (2003). Assessment of sleep and sleepiness in Parkinson disease. Sleep 26, 1049-1054. doi:10.1093/sleep/26.8.1049

Marmion, D. J., and Kordower, J. H. (2018). $\alpha$-Synuclein nonhuman primate models of Parkinson's disease. J. Neural Transm. 125, 385-400. doi:10.1007/ s00702-017-1720-0

Martinez-Valbuena, I., Amat-Villegas, I., Valenti-Azcarate, R., CarmonaAbellandel, M. M., Marcilla, I., Tuñon, M. T., et al. (2018). Interaction of amyloidogenic proteins in pancreatic $\beta$ cells from subjects with synucleinopathies. Acta Neuropathol. 135, 877-886. doi:10.1007/s00401-0181832-0

McCarter, S. J., Boswell, C. L., St. Louis, E. K., Dueffert, L. G., Slocumb, N., Boeve, B. F., et al. (2013). Treatment outcomes in REM sleep behavior disorder. Sleep Med. 14, 237-242. doi:10.1016/j.sleep.2012.09.018
Medeiros, C. A. M., Carvalhedo De Bruin, P. F., Lopes, L. A., Magalhães, M. C., De Lourdes Seabra, M., and Sales De Bruin, V. M. (2007). Effect of exogenous melatonin on sleep and motor dysfunction in Parkinson's disease: a randomized, double blind, placebo-controlled study. J. Neurol. 254, 459-464. doi:10.1007/s00415-006-0390-x

Michel, P. P., Hirsch, E. C., and Hunot, S. (2016). Understanding dopaminergic cell death pathways in Parkinson disease. Neuron 90, 675-691. doi:10.1016/j. neuron.2016.03.038

Mochizuki, H., Choong, C. J., and Baba, K. (2020). Parkinson's disease and iron. J. Neural Transm. 127, 181-187. doi:10.1007/s00702-020-02149-3

Monteiro, L., Souza-Machado, A., Valderramas, S., and Melo, A. (2012). The effect of levodopa on pulmonary function in Parkinson's disease: a systematic review and meta-analysis. Clin. Ther. 34, 1049-1055. doi:10.1016/j.clinthera.2012. 03.001

Naskar, A., Prabhakar, V., Singh, R., Dutta, D., and Mohanakumar, K. P. (2015). Melatonin enhances L-DOPA therapeutic effects, helps to reduce its dose, and protects dopaminergic neurons in 1-methyl-4-phenyl-1,2,3,6tetrahydropyridine-induced parkinsonism in mice. J. Pineal Res. 58, 262-274. doi:10.1111/jpi.12212

Neikrug, A. B., Maglione, J. E., Liu, L., Natarajan, L., Avanzino, J. A., Corey-Bloom, J., et al. (2013). Effects of sleep disorders on the non-motor symptoms of Parkinson disease. J. Clin. Sleep Med. 9, 1119-1129. doi:10.5664/jcsm.3148

Ng, K. Y., Leong, M. K., Liang, H., and Paxinos, G. (2017). Melatonin receptors: distribution in mammalian brain and their respective putative functions. Brain Struct. Funct. 222, 2921-2939. doi:10.1007/s00429-017-1439-6

Nutt, J. G., and Bohnen, N. I. (2018). Non-dopaminergic therapies. J. Parkinsons. Dis. 8, S73-S78. doi:10.3233/JPD-181472

Ortiz, G. G., Moráles-Sánchez, E. W., Pacheco-Moisés, F. P., Jiménez-Gil, F. J., Macías-Islas, M. A., Mireles-Ramírez, M. A., et al. (2017). Efecto de la administración de melatonina sobre la actividad de la ciclooxigenasa-2, la concentración sérica de metabolitos del óxido nítrico, los lipoperóxidos y la actividad de la glutatión peroxidasa en pacientes con enfermedad de Parkinson. Gac. Med. Mex. 153, S72-S81. doi:10.24875/GMM.M000008

Ozdilek, B., and Gunal, D. I. (2012). Motor and non-motor symptoms in Turkish patients with Parkinson's disease affecting family caregiver burden and quality of life. J. Neuropsychiatry Clin. Neurosci. 24, 478-483. doi:10.1176/appi. neuropsych.11100315

Ozsoy, O., Yildirim, F. B., Ogut, E., Kaya, Y., Tanriover, G., Parlak, H., et al. (2015). Melatonin is protective against 6-hydroxydopamine-induced oxidative stress in a hemiparkinsonian rat model. Free Radic. Res. 49, 1004-1014. doi:10.3109/ 10715762.2015.1027198

O'Gorman Tuura, R. L., Baumann, C. R., and Baumann-Vogel, H. (2018). Beyond dopamine: GABA, glutamate, and the axial symptoms of Parkinson disease. Front. Neurol. 9, 806. doi:10.3389/fneur.2018.00806

Palagini, L., Manni, R., Aguglia, E., Amore, M., Brugnoli, R., Girardi, P., et al. (2020). Expert opinions and consensus recommendations for the evaluation and management of insomnia in clinical practice: joint statements of five Italian scientific societies. Front. Psychiatry 11, 558. doi:10.3389/fpsyt.2020.00558

Pandi-Perumal, S. R., Trakht, I., Srinivasan, V., Spence, D. W., Maestroni, G. J. M., Zisapel, N., et al. (2008). Physiological effects of melatonin: role of melatonin receptors and signal transduction pathways. Prog. Neurobiol. 85, 335-353. doi:10.1016/j.pneurobio.2008.04.001

Pappolla, M. A., Matsubara, E., Vidal, R., Pacheco-Quinto, J., Poeggeler, B., Zagorski, M., et al. (2018). Melatonin treatment enhances a $\beta$ lymphatic clearance in a transgenic mouse model of amyloidosis. Curr. Alzheimer Res. 15, 637-642. doi:10.2174/1567205015666180411092551

Patki, G., and Lau, Y. S. (2011). Melatonin protects against neurobehavioral and mitochondrial deficits in a chronic mouse model of Parkinson's disease. Pharmacol. Biochem. Behav. 99, 704-711. doi:10.1016/j.pbb.2011.06.026

Paul, R., Phukan, B. C., Justin Thenmozhi, A., Manivasagam, T., Bhattacharya, P., and Borah, A. (2018). Melatonin protects against behavioral deficits, dopamine loss and oxidative stress in homocysteine model of Parkinson's disease. Life Sci. 192, 238-245. doi:10.1016/j.lfs.2017.11.016

Picillo, M., Erro, R., Amboni, M., Longo, K., Vitale, C., Moccia, M., et al. (2014). Gender differences in non-motor symptoms in early Parkinson's disease: a 2years follow-up study on previously untreated patients. Park. Relat. Disord. 20, 850-854. doi:10.1016/j.parkreldis.2014.04.023 
Poewe, W., Gauthier, S., Aarsland, D., Leverenz, J. B., Barone, P., Weintraub, D., et al. (2008). Diagnosis and management of Parkinson's disease dementia. Int. J. Clin. Pract. 62, 1581-1587. doi:10.1111/j.1742-1241. 2008.01869.x

Porter, B., MacFarlane, R., and Walker, R. (2008). The frequency and nature of sleep disorders in a community-based population of patients with Parkinson's disease. Eur. J. Neurol. 15, 50-54. doi:10.1111/j.1468-1331. 2007.01998.x

Rana, A. Q., Siddiqui, I., Mosabbir, A., Athar, A., Syed, O., Jesudasan, M., et al. (2013). Association of pain, Parkinson's disease, and restless legs syndrome. J. Neurol. Sci. 327, 32-34. doi:10.1016/j.jns.2013.01.039

Rana, A. Q., Vaid, H., Akhter, M. R., Awan, N. Y., Fattah, A., Cader, M. H., et al. (2014). Prevalence of nocturia in Parkinson's disease patients from various ethnicities. Neurol. Res. 36, 234-238. doi:10.1179/1743132813Y. 0000000264

Rasheed, M. Z., Andrabi, S. S., Salman, M., Tabassum, H., Shaquiquzzaman, M., Parveen, S., et al. (2018). Melatonin improves behavioral and biochemical outcomes in a rotenone-induced rat model of Parkinson's disease. J. Environ. Pathol. Toxicol. Oncol. 37, 139-150. doi:10.1615/JEnvironPatholToxicolOncol. 2018025666

Reagan-Shaw, S., Nihal, M., and Ahmad, N. (2008). Dose translation from animal to human studies revisited. FASEB J. 22, 659-661. doi:10.1096/fj.07-9574lsf

Reiter, R. J., Rosales-Corral, S., Tan, D. X., Jou, M. J., Galano, A., and Xu, B. (2017). Melatonin as a mitochondria-targeted antioxidant: one of evolution's best ideas. Cel. Mol. Life Sci. 74, 3863-3881. doi:10.1007/s00018-017-2609-7

Remington, G. (2007). Tardive dyskinesia: eliminated, forgotten, or overshadowed?. Curr. Opin. Psychiatry 20, 131-137. doi:10.1097/YCO. ob013e328017f6bl

Sabaté, M., Rodríguez, M., Méndez, E., Enríquez, E., and González, I. (1996). Obstructive and restrictive pulmonary dysfunction increases disability in Parkinson disease. Arch. Phys. Med. Rehabil. 77, 29-34. doi:10.1016/S00039993(96)90216-6

Saravanan, K. S., Sindhu, K. M., and Mohanakumar, K. P. (2007). Melatonin protects against rotenone-induced oxidative stress in a hemiparkinsonian rat model. J. Pineal Res. 42, 247-253. doi:10.1111/j.1600-079X.2006.00412.x

Schaefer, C., Kunz, D., and Bes, F. (2017). Melatonin effects in REM sleep behavior disorder associated with obstructive sleep apnea syndrome: a case series. Curr. Alzheimer Res. 14. doi:10.2174/1567205014666170523094938

Schirinzi, T., Sancesario, G. M., Di Lazzaro, G., Biticchi, B., Colona, V. L., Mercuri, N. B., et al. (2019). CSF $\alpha$-synuclein inversely correlates with non-motor symptoms in a cohort of PD patients. Park. Relat. Disord. 61, 203-206. doi:10.1016/j.parkreldis.2018.10.018

Sharma, R., McMillan, C. R., Tenn, C. C., and Niles, L. P. (2006). Physiological neuroprotection by melatonin in a 6-hydroxydopamine model of Parkinson's disease. Brain Res. 1068, 230-236. doi:10.1016/j.brainres. 2005.10.084

Shukla, M., Chinchalongporn, V., Govitrapong, P., and Reiter, R. J. (2019). The role of melatonin in targeting cell signaling pathways in neurodegeneration. Ann. N. Y. Acad. Sci. 1443, 75-96. doi:10.1111/nyas.14005

Simon, N., Mouchet, J., and Bruguerolle, B. (2000). Effects of a seven-day continuous infusion of L-DOPA on daily rhythms in the rat. Eur. J. Pharmacol. 401, 79-83. doi:10.1016/S0014-2999(00)00422-2

Singh, E., and Devasahayam, G. (2020). Neurodegeneration by oxidative stress: a review on prospective use of small molecules for neuroprotection. Mol. Biol. Rep. 47, 3133-3140. doi:10.1007/s11033-020-05354-1

Singh, S., Ahmed, R., Sagar, R. K., and Krishana, B. (2006). Neuroprotection of the nigrostriatal dopaminergic neurons by melatonin in hemiparkinsonium rat. Indian J. Med. Res. 124, 419-426. Available at: https://pubmed.ncbi.nlm.nih. gov/17159262/. (Accessed September 8, 2020)

Singhal, N. K., Srivastava, G., Patel, D. K., Jain, S. K., and Singh, M. P. (2011). Melatonin or silymarin reduces maneb- and paraquat-induced Parkinsons disease phenotype in the mouse. J. Pineal Res. 50, 97-109. doi:10.1111/j. 1600-079X.2010.00819.x

Sixel-Döring, F., Trautmann, E., Mollenhauer, B., and Trenkwalder, C. (2011). Associated factors for REM sleep behavior disorder in Parkinson disease. Neurology 77, 1048-1054. doi:10.1212/WNL.0b013e31822e560e

Sugden, D. (1983). Psychopharmacological effects of melatonin in mouse and rat. J. Pharmacol. Exp. Ther. 227, 587-591.
Sundaram, S., Hughes, R. L., Peterson, E., Müller-Oehring, E. M., Brontë-Stewart, H. M., Poston, K. L., et al. (2019). Establishing a framework for neuropathological correlates and glymphatic system functioning in Parkinson's disease. Neurosci. Biobehav. Rev. 103, 305-315. doi:10.1016/j. neubiorev.2019.05.016

Takeuchi, N., Uchimura, N., Hashizume, Y., Mukai, M., Etoh, Y., Yamamoto, K., et al. (2001). Melatonin therapy for REM sleep behavior disorder. Psychiatry Clin Neurosci. 55, 267-269. doi:10.1046/j.1440-1819.2001.00854.x

Tamtaji, O. R., Reiter, R. J., Alipoor, R., Dadgostar, E., Kouchaki, E., and Asemi, Z. (2020). Melatonin and Parkinson disease: current status and future perspectives for molecular mechanisms. Cell. Mol. Neurobiol. 40, 15-23. doi:10.1007/ s10571-019-00720-5

Tan, D.-X., and Reiter, R. J. (2019). Mitochondria: the birth place, battle ground and the site of melatonin metabolism in cells. Melatonin Res. 2, 44-66. doi:10. 32794/mr11250011

Tan, H. Y., Ng, K. Y., Koh, R. Y., and Chye, S. M. (2020). Pharmacological effects of melatonin as neuroprotectant in rodent model: a review on the current biological evidence. Cel. Mol. Neurobiol. 40, 25-51. doi:10.1007/s10571-01900724-1

Tapias, V., Escames, G., López, L. C., López, A., Camacho, E., Carrión, M. D., et al. (2009). Melatonin and its brain metabolite N1-acetyl-5-methoxykynuramine prevent mitochondrial nitric oxide synthase induction in Parkinsonian mice. J. Neurosci. Res. 87, 3002-3010. doi:10.1002/jnr.22123

Trenkwalder, C., Kohnen, R., Högl, B., Metta, V., Sixel-Döring, F., Frauscher, B., et al. (2011). Parkinson's disease sleep scale-validation of the revised version PDSS-2. Mov. Disord. 26, 644-652. doi:10.1002/mds.23476

Tysnes, O. B., and Storstein, A. (2017). Epidemiology of Parkinson's disease. J. Neural Transm. 124, 901-905. doi:10.1007/s00702-017-1686-y

Uz, T., Arslan, A. D., Kurtuncu, M., Imbesi, M., Akhisaroglu, M., Dwivedi, Y., et al. (2005). The regional and cellular expression profile of the melatonin receptor MT1 in the central dopaminergic system. Mol. Brain Res. 136, 45-53. doi:10. 1016/j.molbrainres.2005.01.002

Vecchierini, M. F., Kilic-Huck, U., and Quera-Salva, M. A. (2020). Melatonin (MEL) and its use in neurological diseases and insomnia: recommendations of the French medical and research sleep society (SFRMS). Rev. Neurol. 177, 245. doi:10.1016/j.neurol.2020.06.009

Venegas, C., García, J. A., Doerrier, C., Volt, H., Escames, G., Lõpez, L. C., et al. (2013). Analysis of the daily changes of melatonin receptors in the rat liver. J. Pineal Res. 54, 313-321. doi:10.1111/jpi.12019

Videnovic, A., Noble, C., Reid, K. J., Peng, J., Turek, F. W., Marconi, A., et al. (2014). Circadian melatonin rhythm and excessive daytime sleepiness in Parkinson disease. JAMA Neurol. 71, 463-469. doi:10.1001/jamaneurol.2013. 6239

Willis, G. L., and Armstrong, S. M. (1999). A therapeutic role for melatonin antagonism in experimental models of Parkinson's disease. Physiol. Behav. 66, 785-795. doi:10.1016/S0031-9384(99)00023-2

Willis, G. L., and Freelance, C. B. (2018). Emerging preclinical interest concerning the role of circadian function in Parkinson's disease. Brain Res. 1678, 203-213. doi:10.1016/j.brainres.2017.09.027

Willis, G. L., Kelly, A. M. A., and Kennedy, G. A. (2008). Compromised circadian function in Parkinson's disease: enucleation augments disease severity in the unilateral model. Behav. Brain Res. 193, 37-47. doi:10.1016/j.bbr.2008.04.017

Willis, G. L., and Turner, E. J. D. (2007). Primary and secondary features of Parkinson's disease improve with strategic exposure to bright light: a case series study. Chronobiol. Int. 24, 521-537. doi:10.1080/07420520701420717

Wilson, S. J., Nutt, D. J., Alford, C., Argyropoulos, S. V., Baldwin, D. S., Bateson, A. N., et al. (2010). British Association for Psychopharmacology consensus statement on evidence-based treatment of insomnia, parasomnias and circadian rhythm disorders. J. Psychopharmacol. 24, 1577-1600. doi:10.1177/ 0269881110379307

Winge, K., Skau, A. M., Stimpel, H., Nielsen, K. K., and Werdelin, L. (2006). Prevalence of bladder dysfunction in Parkinsons disease. Neurourol. Urodyn. 25, 116-122. doi:10.1002/nau.20193

Wong, J. C., Li, Y., Schwarzschild, M. A., Ascherio, A., and Gao, X. (2014). Restless legs syndrome: an early clinical feature of Parkinson disease in men. Sleep 37, 369-372. doi:10.5665/sleep. 3416

Xue, P., Wang, T., Zong, H. T., and Zhang, Y. (2014). Urodynamic analysis and treatment of male Parkinson's disease patients with voiding 
dysfunction. Chin. Med. J. 127, 878-881. doi:10.3760/cma.j.issn.03666999.20132695

Yildirim, F. B., Ozsoy, O., Tanriover, G., Kaya, Y., Ogut, E., Gemici, B., et al. (2014). Mechanism of the beneficial effect of melatonin in experimental Parkinson's disease. Neurochem. Int. 79, 1-11. doi:10.1016/j.neuint.2014.09.005

Zaitone, S. A., Hammad, L. N., and Farag, N. E. (2013). Antioxidant potential of melatonin enhances the response to L-dopa in 1-methyl 4-phenyl 1,2,3,6tetrahydropyridine-parkinsonian mice. Pharmacol. Rep. 65, 1213-1226. doi:10. 1016/S1734-1140(13)71479-8

Zemková, H., and Vaněček, J. (1997). Inhibitory effect of melatonin on gonadotropin-releasing hormone-induced $\mathrm{Ca} 2+$ Oscillations in pituitary cells of newborn rats. Neuroendocrinology 65, 276-283. doi:10.1159/000127185

Zhong, G., Bolitho, S., Grunstein, R., Naismith, S. L., and Lewis, S. J. G. (2013). The relationship between thermoregulation and REM sleep behaviour disorder in Parkinson's disease. PLoS One 8. doi:10.1371/journal.pone.0072661
Zisapel, N., Egozi, Y., and Laudon, M. (1982). Inhibition of dopamine release by melatonin: regional distribution in the rat brain. Brain Res. 246, 161-163. doi:10.1016/0006-8993(82)90157-3

Conflict of Interest: The authors declare that the research was conducted in the absence of any commercial or financial relationships that could be construed as a potential conflict of interest.

Copyright (c) 2021 Pérez-Lloret and Cardinali. This is an open-access article distributed under the terms of the Creative Commons Attribution License (CC $B Y)$. The use, distribution or reproduction in other forums is permitted, provided the original author(s) and the copyright owner(s) are credited and that the original publication in this journal is cited, in accordance with accepted academic practice. No use, distribution or reproduction is permitted which does not comply with these terms. 